\title{
Comparative Ecology of Capsular Exophiala Species Causing Disseminated Infection in Humans
}

\section{OPEN ACCESS}

Edited by:

Hector Mora Montes,

Universidad de Guanajuato, Mexico

Reviewed by:

Alexandro Bonifaz,

Hospital General de México, Mexico José Ascención Martínez-Álvarez, University of Guanajuato, Mexico

*Correspondence:

Ruоуu Li

mycolab@126.com

Sybren de Hoog

s.hoog@westerdijkinstitute.nl

Specialty section:

This article was submitted to

Fungi and Their Interactions,

a section of the journal

Frontiers in Microbiology

Received: 30 October 2017

Accepted: 04 December 2017

Published: 19 December 2017

Citation:

Song Y, Laureijssen-van de Sande WWJ, Moreno LF, Gerrits van den Ende B, Li R and de Hoog S

(2017) Comparative Ecology of

Capsular Exophiala Species Causing

Disseminated Infection in Humans.

Front. Microbiol. 8:2514.

doi: 10.3389/fmicb.2017.02514

\author{
Yinggai Song 1, 2, 3, 4, Wendy W. J. Laureijssen-van de Sande ${ }^{5}$, Leandro F. Moreno ${ }^{4}$, \\ Bert Gerrits van den Ende ${ }^{4}$, Ruoyu $\mathrm{Li}^{1,2,3 *}$ and Sybren de Hoog ${ }^{4,6 *}$ \\ ${ }^{1}$ Department of Dermatology, Peking University First Hospital, Beijing, China, ${ }^{2}$ Research Center for Medical Mycology, \\ Peking University, Beijing, China, ${ }^{3}$ Beijing Key Laboratory of Molecular Diagnosis of Dermatoses, Peking University First \\ Hospital, Beijing, China, ${ }^{4}$ Westerdijk Fungal Biodiversity Institute, Utrecht, Netherlands, ${ }^{5}$ Department of Medical Microbiology \\ and Infectious Diseases, Erasmus MC, University of Rotterdam, Rotterdam, Netherlands, ${ }^{6}$ Center of Expertise in Mycology \\ Radboudumc/CWZ, Radboud University Nijmegen Medical Center, Nijmegen, Netherlands
}

Exophiala spinifera and Exophiala dermatitidis (Fungi: Chaetothyriales) are black yeast agents potentially causing disseminated infection in apparently healthy humans. They are the only Exophiala species producing extracellular polysaccharides around yeast cells. In order to gain understanding of eventual differences in intrinsic virulence of the species, their clinical profiles were compared and found to be different, suggesting pathogenic strategies rather than coincidental opportunism. Ecologically relevant factors were compared in a model set of strains of both species, and significant differences were found in clinical and environmental preferences, but virulence, tested in Galleria mellonella larvae, yielded nearly identical results. Virulence factors, i.e., melanin, capsule and muriform cells responded in opposite direction under hydrogen peroxide and temperature stress and thus were inconsistent with their hypothesized role in survival of phagocytosis. On the basis of physiological profiles, possible natural habitats of both species were extrapolated, which proved to be environmental rather than animal-associated. Using comparative genomic analyses we found differences in gene content related to lipid metabolism, cell wall modification and polysaccharide capsule production. Despite the fact that both species cause disseminated infections in apparently healthy humans, it is concluded that they are opportunists rather than pathogens.

Keywords: black yeast, capsule, Exophiala species, virulence, pathogenicity, opportunism, physiology, Galleria mellonella

\section{INTRODUCTION}

The black yeast genus Exophiala (Fungi, order Chaetothyriales) contains about 40 species, 17 of which have been reported from human infections (De Hoog et al., 2000b; Revankar and Sutton, 2010). Some species are notorious agents of deep and disseminated human infection, in debilitated but also in healthy individuals (Revankar et al., 2002). In contrast to frequent statements in the literature, Exophiala black yeasts are not common saprobes on plant debris but are selected by domesticated environments where conditions for microbial growth are relatively hostile. Their survival strategy has been referred to as polyextremotolerant (Gostincar et al., 2011). 
Of all Exophiala species, Exophiala dermatitidis (E. dermatitidis) and Exophiala spinifera (E. spinifera) are associated with the most severe infections, which in systemic cases have high mortality rates of up to $80 \%$ (Rajam et al., 1958; Crosby et al., 1989; Campos-Takaki and Jardim, 1994; de Hoog et al., 2005; Radhakrishnan et al., 2010; Li et al., 2011; Patel et al., 2013; Hu et al., 2014; Wang et al., 2015; Chen et al., 2016). As a possible explanation of their relatively high virulence compared to other Exophiala species, the occurrence of extracellular polysaccharide on yeast cells has been mentioned, masking the cells for human phagocytes upon tissue invasion (Yurlova and de Hoog, 2002). Exophiala dermatitidis has a global distribution in the domesticated environment, but cases of deep phaeohyphomycosis are nearly exclusively found in East Asia (Revankar et al., 2002; Kantarcioglu et al., 2004). In Europe the fungus occurs as a respiratory colonizer in patients with cystic fibrosis (Kondori et al., 2011). In contrast to many other opportunistic fungi its frequency seems to be relatively unaffected by the growing hospitalized populations of patients with compromised immunity. Extended searches for the fungus in the natural environment yielded feces of frugivorous tropical animals as a possible niche, while prevalence in soil and plant debris was close to zero (Sudhadham et al., 2008). The species is however commonly found in indoor wet cells such as bathing facilities and dishwashers (Matos et al., 2002; Gümral et al., 2015) and other human-made environments such as creosoted railway sleepers (Gumral et al., 2014). These habitats are characterized by (i) high temperatures, (ii) osmotic stress, (iii) acidic or alkaline conditions, and (iv) toxicity along with (v) low nutrient availability. It has been speculated that such strongly selective environments may drive their evolution toward human pathogenicity (Gostincar et al., 2011; Dogen et al., 2013b; Zupancic et al., 2016).

Exophiala spinifera is rare, both in humans and in the environment. Disseminated infections may have a fatal outcome and were prevalently observed in immunocompetent children and adolescents, while in the elderly infections tend to remain as (sub) cutaneous lesions, taking a mild course despite underlying disorders (de Hoog et al., 1999). The species has not been reported from CF lungs. Its environmental occurrence displays a rather scattered picture.

The ecological differences between E. dermatitidis and E. spinifera are intriguing. Both are characterized by the production of extracellular slimes, which may be either in the form of a well-delimited capsule or of diffusely exuded exopolysaccharides (EPS). The capsular material was reported around very young cells of E. spinifera and acid mucopolysaccharides were observed around yeast cells of E. dermatitidis (Yurlova and de Hoog, 2002). In general, capsular material is a key determinant of virulence, as extracellular polysaccharides have a significant role in adherence, impairment of phagocytosis and to reduce complement-mediated killing (Nishimura and Miyaji, 1983). If the two species are opportunists without pathogenic strategies, the average clinical course of both is expected to be similar, i.e., dependent on host conditions and route of infection. Alternatively, the striking differences between the two species have to be explained by their environmental behavior. In the present study our systematic approach involves growth, morphology of invasive phases, multilocus sequencing, and physiology, while relative virulence was determined in a Galleria mellonella larvae model. In addition, we assessed the genomes of E. spinifera and E. dermatitidis in order to provide gene information on the physiological variations observed between the species.

\section{MATERIALS AND METHODS}

\section{Literature Search}

Keywords "Exophiala spinifera," "Exophiala dermatitidis," and "Wangiella dermatitidis" were used in PubMed to search for English literature including research articles, reviews and case reports published until January 2017. In addition, research databases available at Westerdijk Institute were consulted.

\section{Strains Studied}

A global set of 48 E. spinifera isolates (26 clinical, 22 environmental) and $47 \mathrm{E}$. dermatitidis isolates (28 clinical, 19 environmental) were available for study (Table 1). Strains were obtained from the Research Center for Medical Mycology at Peking University and the Centraalbureau voor Schimmelcultures (housed at Westerdijk Fungal Biodiversity Institute, Utrecht, The Netherlands) from 1997 to 2016. Representatives of genotypes A1, A2, A3, genotype B, and genotype $\mathrm{C}$ of E. dermatitidis were included (Table 1). Data of prevalence of the two species were abstracted from a research database on black yeasts at Westerdijk Institute, comprising ITS and part of TEF1 sequenced items of E. spinifera and E. dermatitidis, respectively.

Twenty E. spinifera strains and twenty E. dermatitidis strains (Table 1), representing maximum ecological and geographical variation, were selected for physiology testing and the $G$. mellonella virulence model. Identity of strains was verified by sequencing.

\section{DNA Extraction}

Genomic DNA was obtained from strains grown for 7-14 day on MEA at $24^{\circ} \mathrm{C}$. All cultures were handled within a class II biological safety cabinet. Extraction was followed by the cetyltrimethylammonium bromide (CTAB) protocol according to CBS. Quality and quantity of isolated DNA was verified on a NanoDrop ND-1000 Spectrophotometer using ND-1000 v3.3.0 software (Coleman Technologies, Wilmington, DE, USA). Samples were stored at $-20^{\circ} \mathrm{C}$.

\section{DNA Amplification and Sequencing}

The following nuclear genes were amplified by PCR: rDNA internal transcribed spacer region (ITS), partial transcriptional elongation factor 1 subunit $\alpha(T E F 1-\alpha)$, and $\beta$-tubulin (TUB). ITS of the rDNA operon was amplified with ITS1 and ITS4. Partial $\beta$-tubulin $(T U B)$, covering the variable $5^{\prime}$-end containing four small introns, was amplified with TUB2a and TUB2b, the partial gene TEF1- $\alpha$ with EF1-728F and EF1-986R primer set. Conditions for amplifications of all genes were as described by de Hoog et al. (2011). Sequencing was done with an ABI3730 
TABLE 1 | Strains analyzed of E. spinifera and E. dermatitidis.

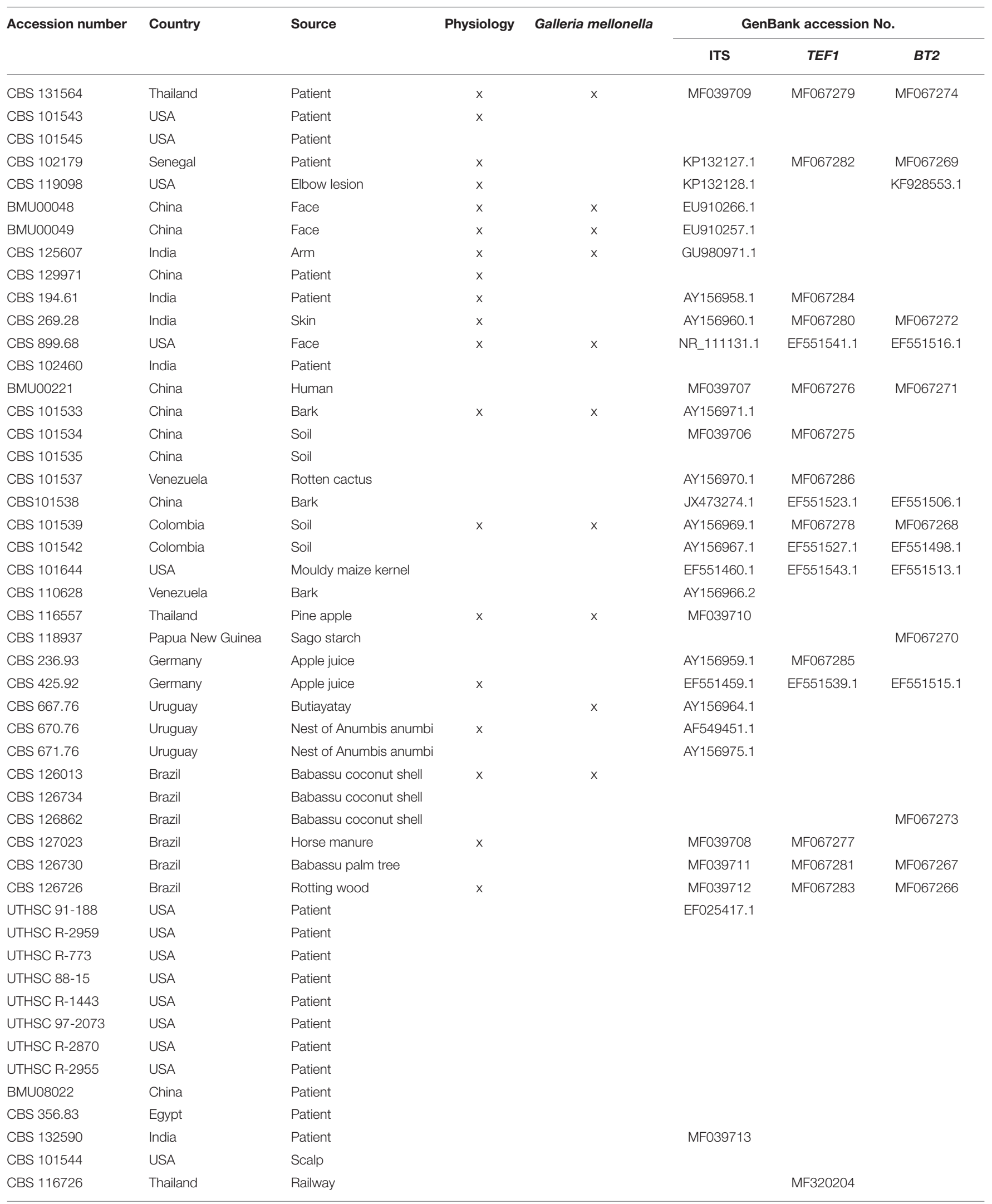


TABLE 1 | Continued

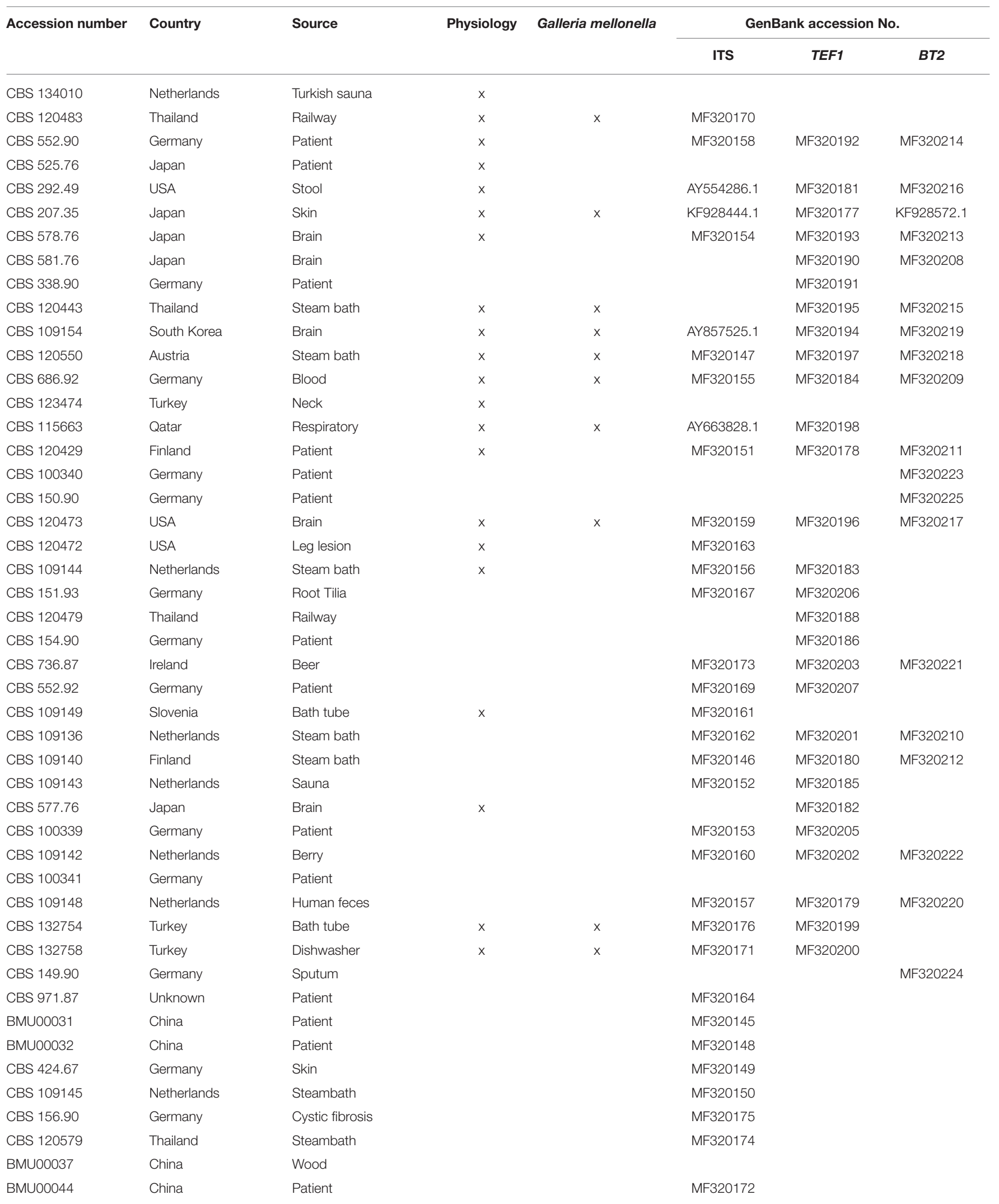

$x$, Strains used in subsequent experiments (physiology and Galleria model). 
automatic sequencer (Applied Biosystems, Foster City, CA, USA) and sequence data were adjusted by SeqManPro (DNAStar, Madison, WI, USA). GenBank accession numbers are given in Table 1. We selectively submitted some of the sequences per clade.

\section{Alignment and Phylogenetic Reconstruction}

For phylogenetic reconstructions with different loci resulting in different degrees of resolution, appropriate reference sequences were obtained from GenBank. Multiple sequence alignments were created with online MAFFT v7 using automatic alignment strategy. Alignments were reviewed and corrected manually. Ambiguously aligned regions, long gaps and introns were removed from the alignments using BIOEDIT v7.1.3.0. Phylogenetic reconstructions were done for each locus using maximum likelihood (ML) implemented in MEGA v6.06, and MRBAYES trees were done via the CiPRES portal (http://www. phylo.org/). MEGA v6.06 selected $\mathrm{K} 2+\mathrm{G}$ as the most appropriate model of DNA substitution for ML analysis. Support for the internodes was assessed by bootstrap analysis from 1,000 replicates. Trees were viewed and edited with MEGA v6.06, FIGTREE v1.4.2 and Adobe Illustrator CS6.

\section{Morphology}

Slides were made by Shear's mounting medium without pigments. Micrographs were taken using a Nikon Eclipse 80i microscope and DS Camera Head DS-Fil/DS-5 m/DS2Mv/DS-2MBW using NIS-Element freeware package (Nikon Europe, Badhoevedorp, The Netherlands). Dimensions were taken with the Nikon Eclipse 80i measurement module on slides and the mean and standard deviation were calculated from measurements of 40-50 conidia.

Twenty E. spinifera and twenty E. dermatitidis strains were tested for the production of muriform cells known as the invasive phase of human chromoblastomycosis. Strains were incubated at 25 and $37^{\circ} \mathrm{C}$ for 1 week in liquid acidic medium ( $30 \mathrm{~g}$ glucose, $3 \mathrm{~g} \mathrm{NaNO}_{3}, 0.01 \mathrm{~g} \mathrm{FeSO}_{4} \cdot 7 \mathrm{H}_{2} \mathrm{O}, 0.265 \mathrm{~g} \mathrm{NH}_{4} \mathrm{Cl}, 0.003 \mathrm{~g}$ thiamin, $1 \mathrm{mM} \mathrm{CaCl}_{2}$ in $1 \mathrm{~L} \mathrm{dH}_{2} \mathrm{O}$, pH adjusted at 2.5 with $\mathrm{HCl}$ ) shaken at 150 r.p.m (Karuppayil and Szaniszlo, 1997).

\section{Capsule}

Strains were maintained on Potato Dextrose Agar (PDA) slants, inoculated on fresh PDA plates at 24 and $37^{\circ} \mathrm{C}$ and incubated for 7 days. Presence of extracellular polysaccharide was verified regularly during 2-7 days of growth and capsular sizes were measured with negative staining in India ink (Yurlova and de Hoog, 2002). All tests were performed three times in duplicate. Numerical values are the means of at least 20 determinations.

\section{Physiology}

All tests were done with 20-selected E. spinifera and 20 E. dermatitidis strains. Cardinal growth temperatures were determined on $2 \%$ malt extract agar (MEA; Difco). Plates were incubated at $15-45^{\circ} \mathrm{C}$ with $3^{\circ} \mathrm{C}$ intervals in the dark for 2 weeks; plates contained double quantities of medium and were sealed to prevent drying out. Colony diameters were measured for a selection of 20 E. spinifera strains and 20 E. dermatitidis strains based on phylogenetic results and references. In addition, growth responses at 40 and $45^{\circ} \mathrm{C}$ were recorded. To evaluate whether 40 and $45^{\circ} \mathrm{C}$ were fungicidal, the cultures were returned to $24^{\circ} \mathrm{C}$ after 2 weeks and incubated for two additional weeks. Experiments consisted of three simultaneous replicates for each isolate; the entire procedure was repeated once.

Lipases were tested with Tween 80 opacity test medium (TOTM) according to Slifkin (Slifkin, 2000), incubating Petri dishes at $24^{\circ} \mathrm{C}$ for 14 day. Proteolysis was tested with Bromocresol purple-milk solids-glucose agar (BCP-MS-G) medium (Fischer and Kane, 1971; Summerbell et al., 1988) using colony fragments as inoculum. After incubation at $24^{\circ} \mathrm{C}$ for $14 \mathrm{~d}$, color changes of the medium were recorded. Haemolytic activity was evaluated by culturing isolates on blood agar (BioMérieux, Marcy-l'Étoile, France) for $14 \mathrm{~d}$ at $24^{\circ} \mathrm{C}$. Positive reaction is a clear ring of hemolysis around the colony. Production of urease was determined in Christensen's urea broth after incubation at 24 and $37^{\circ} \mathrm{C}$ for 8 and $24 \mathrm{~h}$, with a final check after 7 day. Acid productions was tested on Custer's chalk medium including $5 \%$ glucose and $0.5 \%$ calcium carbonate after incubation at $25^{\circ} \mathrm{C}$ for 2 weeks.

Oxygenic stress was evaluated with cultures in YEPD agar medium with hydrogen peroxide to reach concentrations of $3,6,9$, and $12 \mathrm{mM}$ after sterilization. Growth rates and morphology were recorded. Cycloheximide 0.2\% (SigmaAldrich, Zwijndrecht, The Netherlands) tolerance was evaluated by growing isolates on SGA with and without cycloheximide incubated at 24 and $37^{\circ} \mathrm{C}$ for 2 wks. Osmotolerance was tested with YPD basic medium with 20, 40 and 60\% sucrose. Halotolerance was tested with complete medium with $2.5,5$, and $10 \% \mathrm{NaCl}$ and $\mathrm{MgCl}_{2}$.

\section{Protein Family Classification}

For functional annotation of protein sets corresponding to E. dermatitidis CBS 525.76 and E. spinifera CBS 899.68, sequences were retrieved from the Black Yeast Genome Database (Moreno et al., 2017). Genes correlated with capsule production were predicted by identifying orthologs using the OrthoMCL pipeline, previously described in Cryptococcus neoformans (Gish et al., 2016). Lipase family classification was performed based on the top BLAST hit (cut-off $e$-value $>1 e^{-15}$ ) to the lipaseengineering database (Barth et al., 2004). Genes involved in the nitrogen metabolism were predicted mapping selected urease genes known from previously work (Carlini and Ligabue-Braun, 2016). Catalase/peroxidases genes were predicted via top BLAST hit (cut-off $e$-value $>1 \mathrm{e}^{-15}$ ) to the PeroxiBase (Fawal et al., 2013). Cell wall associated genes and potential peptidases were derived from the Black Yeast Genome Database (Moreno et al., 2017).

\section{Virulence in Galleria mellonella}

Conidia cells were harvested from MEA-grown cultures incubated for 7 days at $33^{\circ} \mathrm{C}$. Conidia were counted in a Bürker-Turk counting chamber and a standardized conidial suspension was made. This suspension consisted of $10^{7}-10^{4}$ conidia per larvae. To verify the number of colony forming 
units, $40 \mu \mathrm{L}$ of $10^{3}$ and $10^{2}$ inoculums were placed on SGA plates with gentamycin. Plates were incubated for 14 days at $37^{\circ} \mathrm{C}$ and colonies were counted. To inject the larvae, $40 \mu \mathrm{L}$ of the conidia suspension was injected into the haemocoel of G. mellonella larvae via the last left proleg with an insulin micro-syringe. As a control in each experiment, one G. mellonella group was injected with PBS only. Each strain was tested in three independent experiments in separate weeks. Viability of the larvae was checked daily. Any cocoons formed, were disregarded and left out of the equations. Values were presented as the mean obtained from the three separate experiments and differences were analyzed with the Mann-Whitney $U$-test; statistical significance was set at $P<0.05$ using GraphPad Prism 5 (GraphPad, La Jolla, CA, USA) and SPSS 19.0 (IBM, USA) softwares.

\section{RESULTS}

\section{Habitats of E. dermatitidis and E. spinifera}

Exophiala dermatitidis is a relatively widespread fungus in the environment, although mostly occurring in low abundance. An extensive ecological study was performed by Sudhadham et al. (2008), who searched for the species in numerous natural and domestic environments and detected the species in fruit samples, feces of frugivorous birds, and natural hot springs, but particularly in steam baths and on creosoted railway sleepers. Other studies (Dogen et al., 2013a; Gümral et al., 2015; Zupancic et al., 2016) confirmed the prevalence in bathing facilities, on railway sleepers, and in dishwashers. Common fungal habitats as plant debris and soil were consistently negative or nearly so. Thus, the fungus seems selected by either toxic, or by hot, moist and nutritionally poor environments.

Exophiala spinifera is a rare fungus in the environment. We analyzed almost all strains globally available in the literature and the research database available at Westerdijk Institute (Table 1). Strains originated from plant materials with high sugar content, such as pineapple, maize, sugarcane, rotten cactus, and apple juice. The species was particularly prevalent on decomposing scales of babassu coconuts (Nascimento et al., 2017), which are rich in lipids, terpenes and aromatic hydrocarbons (Figure 1). Creosoted wood, bathing facilities and dishwashers, but also soil and plant debris were consistently negative. Thus, the fungus seems selected by somewhat osmotic environments; its prevalence in the coconut habitat requires further study.

In the human patient, E. dermatitidis occurs on (sub) cutaneous locations causing otitis externa, keratitis, and onychomycosis (Matsumoto et al., 1993; De Hoog et al., 2000a), but is more frequently found systemically, regularly colonizing the lungs of patients with cystic fibrosis (CF) (Horre et al., 2004; Chotirmall and McElvaney, 2014) and the intestinal tract of debilitated patients (Matos et al., 2002; de Hoog et al., 2005). Until January 2017, 77 cases (Table 2) have been reported in the English literature; 39 cases (Table 2) are single systemic infections (excluding pseudoepidemics). Life-threatening systemic infections occur in patients underlying disorders but also in otherwise healthy individuals (Alabaz et al., 2009) (51\%,

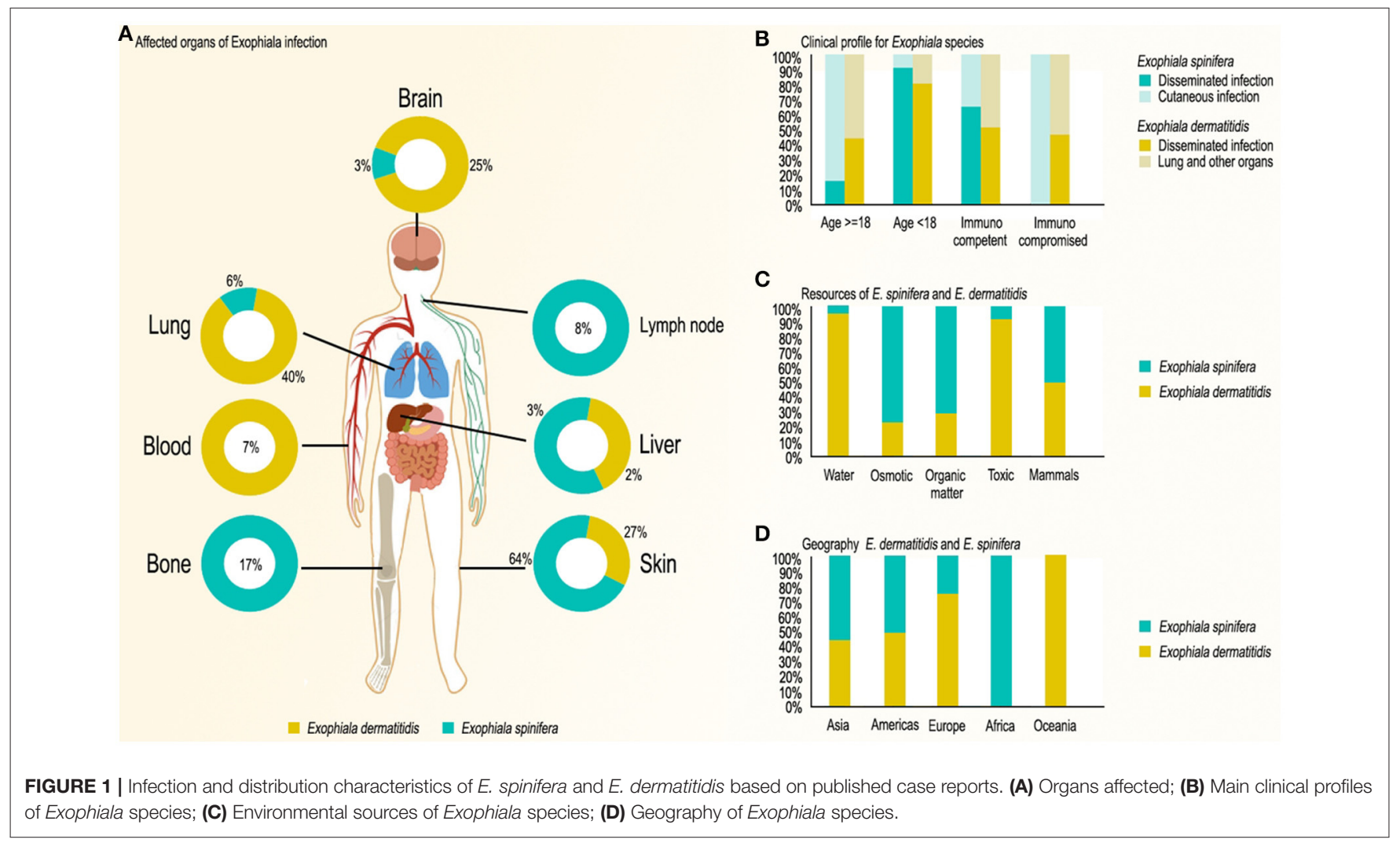




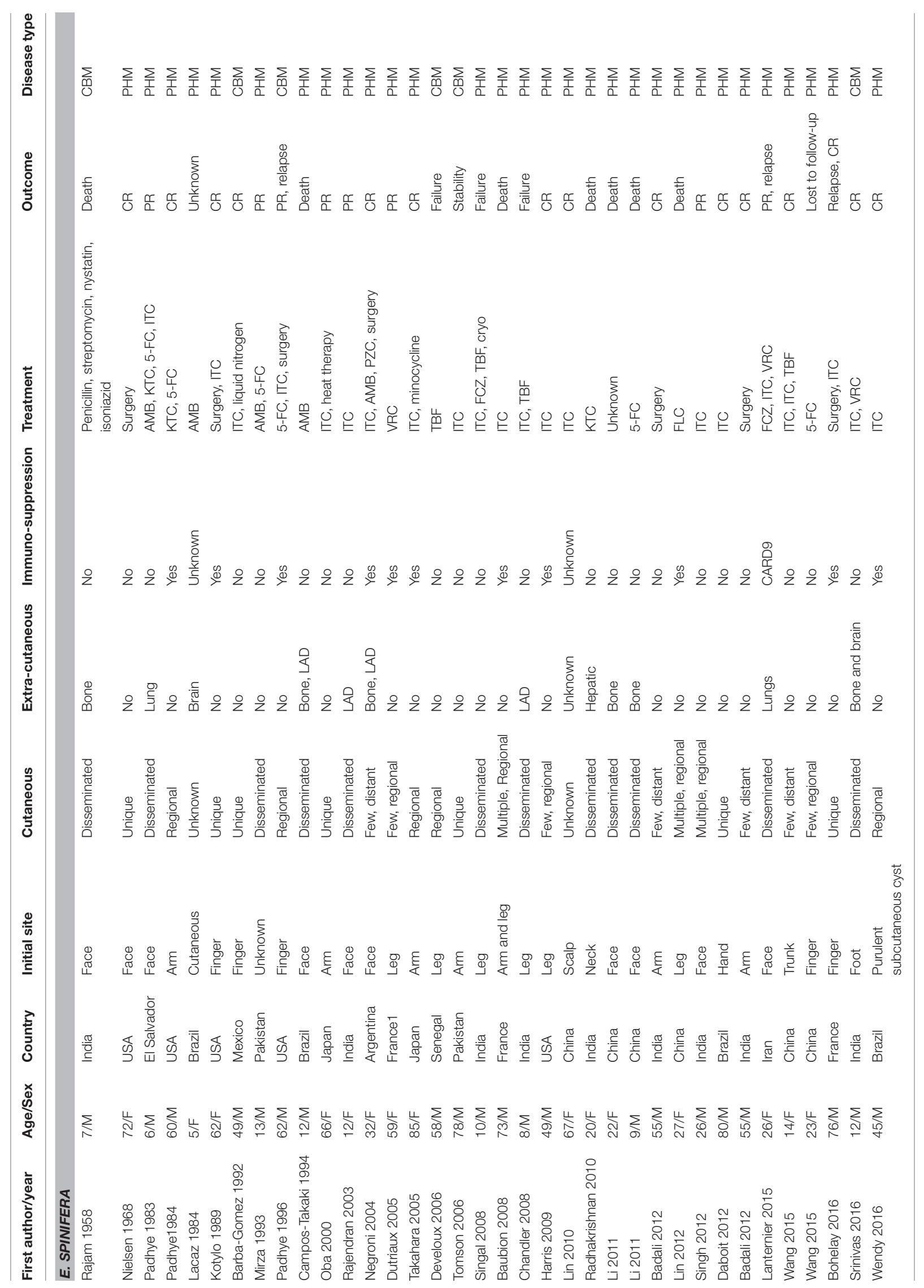




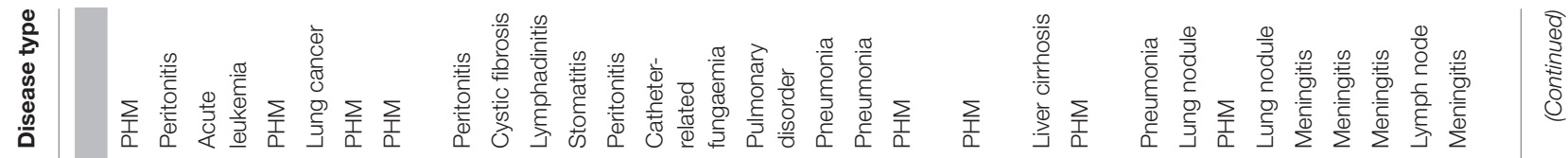

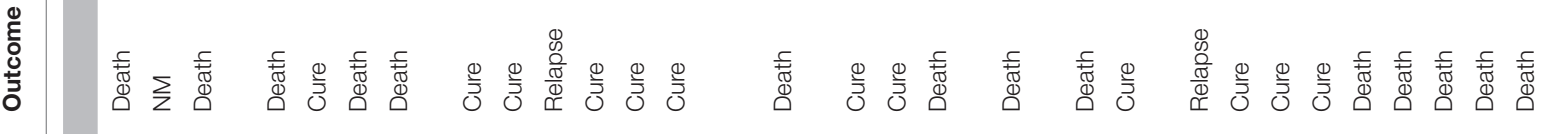

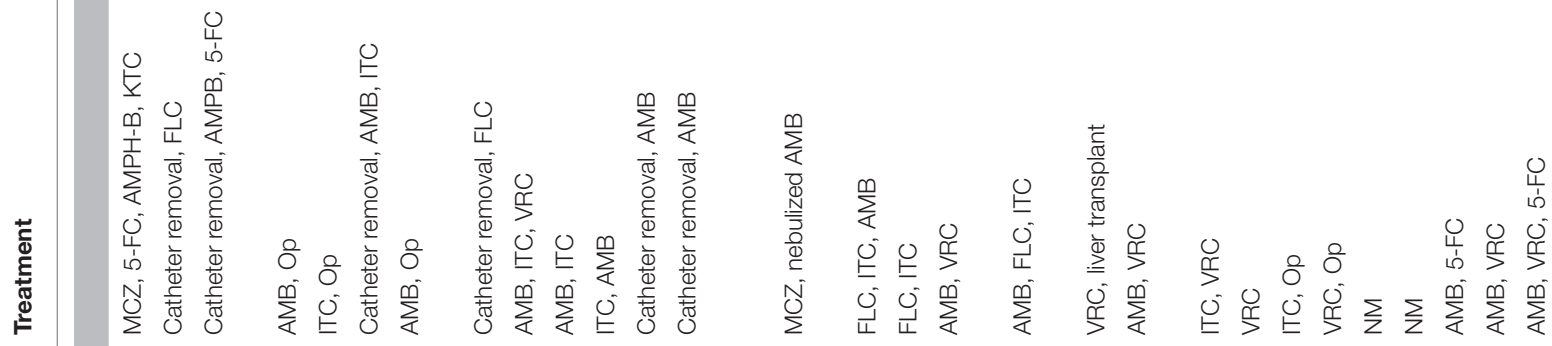

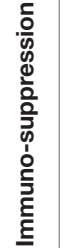

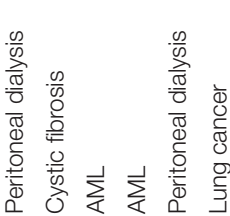

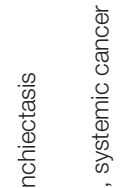

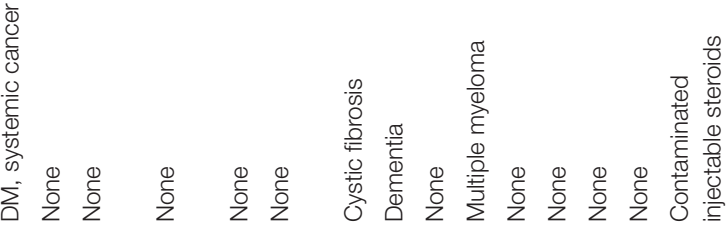

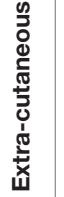

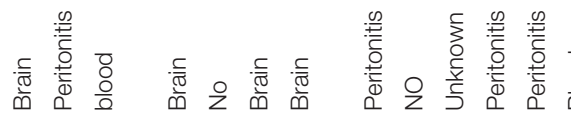

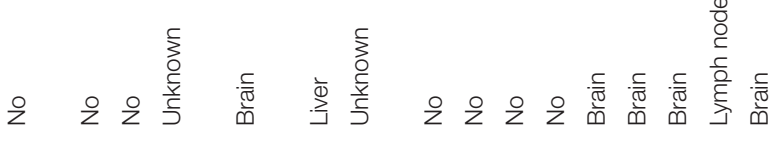

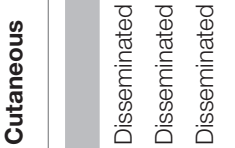

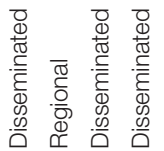

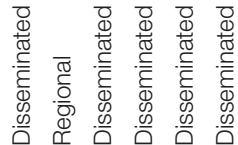

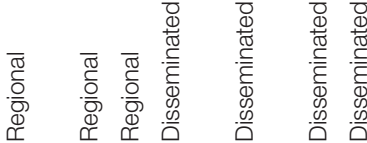

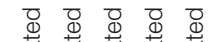




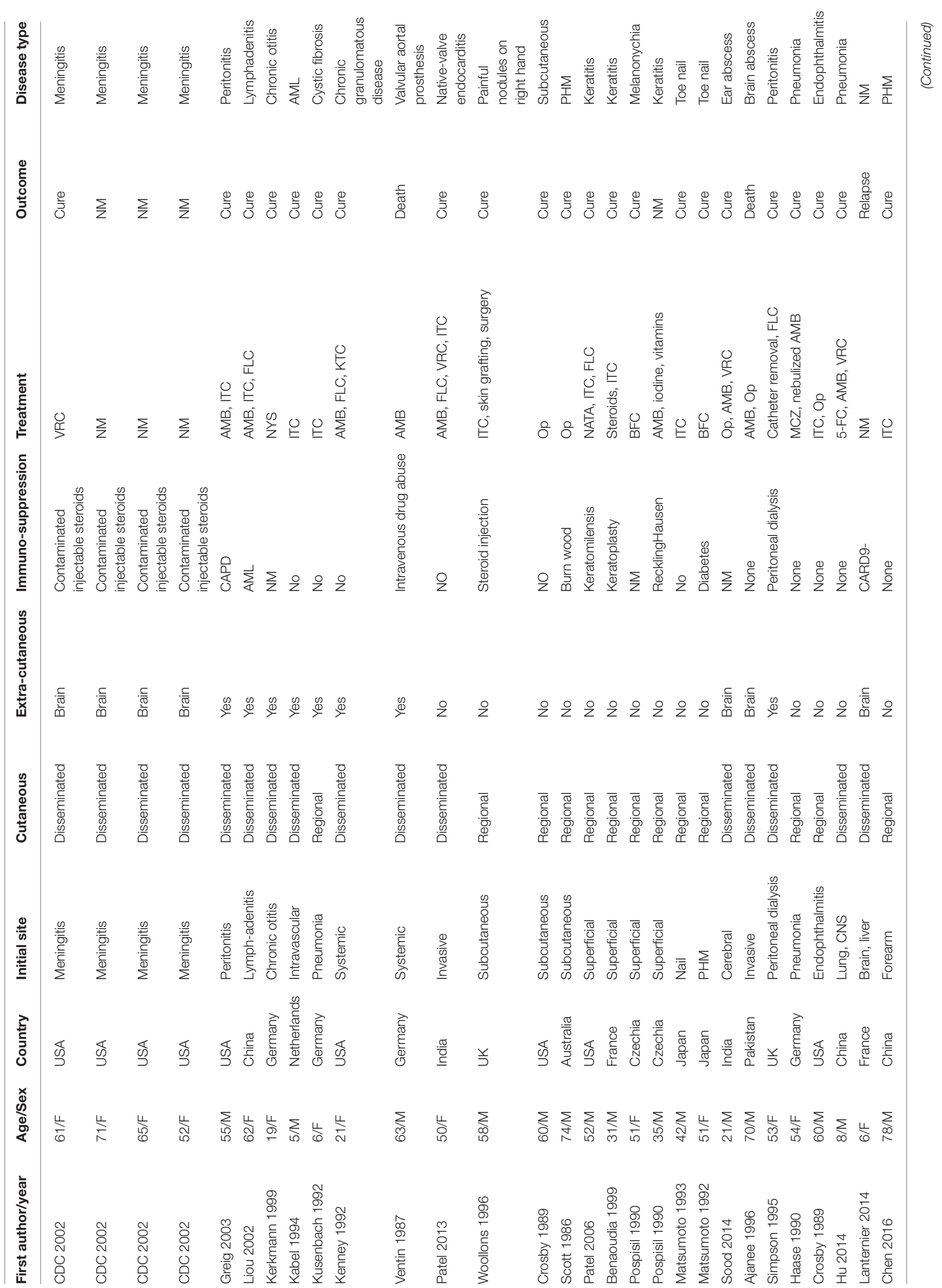




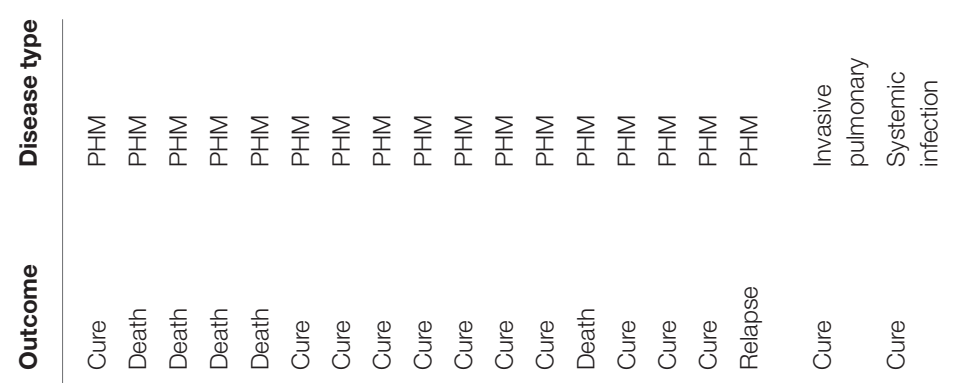

蒙蓠

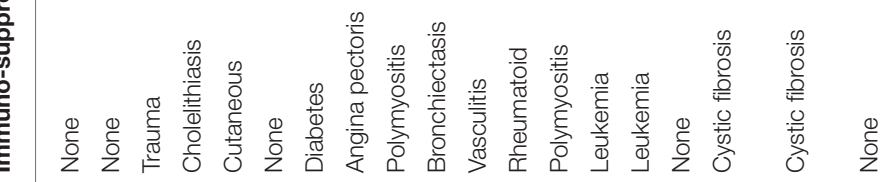

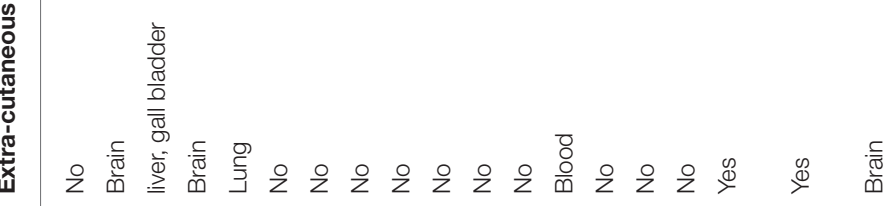

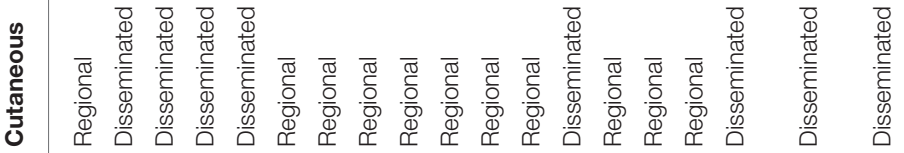

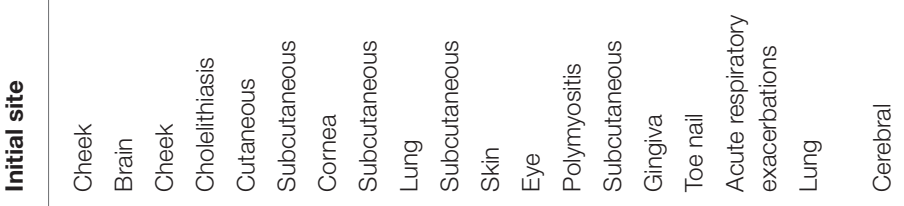

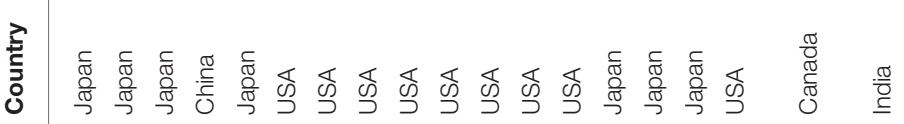

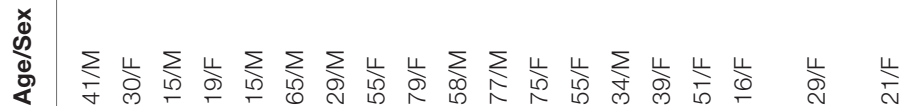


39/77) particularly in those of Asian descent (Sudhadham et al., 2008) (62\%, 24/39). Among the 39 systemic infections, 14 cases showed neurotropism while none was osteotropic; 34 of the cases concerned immunocompetent patiens. Two case series concerned injection of contaminated fluids into the bloodstream of patients, where neurotropism was frequently observed (Matsumoto et al., 1993). A case a fatality rate of over $80 \%$ was noted in systemic infections (Patel et al., 2013; Table 2).

In contrast, E. spinifera is rarely involved in infections limited to the skin. Some cases (Rajam et al., 1958; BarbaGomez et al., 1992; Padhye et al., 1996; Develoux et al., 2006; Tomson et al., 2006; Srinivas et al., 2016) were reported as chromoblastomycosis, although typical muriform cells were mostly lacking. Fatal systemic infections are known; 36 cases have been recorded in English and Chinese literature (Rajam et al., 1958; Nishimura and Miyaji, 1983; Padhye et al., 1983, 1984; Mirza et al., 1993; Campos-Takaki and Jardim, 1994; de Hoog et al., 1999; Rajendran et al., 2003; Negroni et al., 2004; Dutriaux et al., 2005; Baubion et al., 2008; Singal et al., 2008; Fothergill et al., 2009; Harris et al., 2009; Radhakrishnan et al., 2010; Li et al., 2011; Badali et al., 2012; Daboit et al., 2012; Lin et al., 2012; Bohelay et al., 2016; Silva et al., 2017; Table 2). Among the 12 systemic infections, all cases concerned immunocompetent patients. Osteotropism was mentioned in 5 cases, neurotropism in one case. An Asian predilection was notable (83\%, 10/12). The fungus has not been encountered in CF lungs.

\section{Geography}

Exophiala dermatitidis is known from natural habitats from tropical regions and has been reported in Brazil (Reiss and
Mok, 1979), Nigeria (Muotoe-Okafor and Gugnani, 1993), and Thailand (Sudhadham et al., 2008; Zeng and De Hoog, 2008). In the domestic, man-made environment and in patients the fungus has a global distribution (Sudhadham et al., 2008; Zeng and De Hoog, 2008). Numerous isolates have been recorded from e.g., the following countries: Germany (Horre et al., 2004), Italy, Japan (Hiruma et al., 1993), Slovenia (Zalar et al., 2011), Sweden (Kondori et al., 2011), The Netherlands (de Hoog et al., 2005), Turkey (Dogen et al., 2013b), and USA (Zeng et al., 2007), covering several continents. E. spinifera was found to have a similar global distribution judging from literature and 48 available strains, with a slight bias to (sub) tropical regions: Argentina, Brazil, China, Colombia, Germany, India, Italy, Mexico, Papua New Guinea, Senegal, Thailand, and USA (Figure 1). Most of the isolates concerned patient materials.

\section{Diversity}

Exophiala dermatitidis is known to have three main genotypes in ITS, viz. A, B, and C (Rath et al., 1997; Sudhadham et al., 2010), of which genotype A has been subdivided further (Rath et al., 1997). Single-gene trees of TEF1 and TUB showed that there is random variation among partitions. This indicates that the published ITS haplotypes represent different variants of a single species. Haplotype diversity (Rozas and Rozas, 1995) for E. dermatitidis was as follows, TEF1: $h=10, \mathrm{Hd}=0.4825 ;$ TUB: $h=12$, Hd $=0.6626$, ITS: $h=10, \mathrm{Hd}=0.7077$. The same parameters for E. spinifera were: TEF1: $h=10, \mathrm{Hd}=0.4541, T U B$ : $h=11, \mathrm{Hd}=0.8415$, ITS: $h=12, \mathrm{Hd}=0.7606$. No consistent difference was found in the multilocus tree between clinical and environmental strains, indicating that isolates from patients are

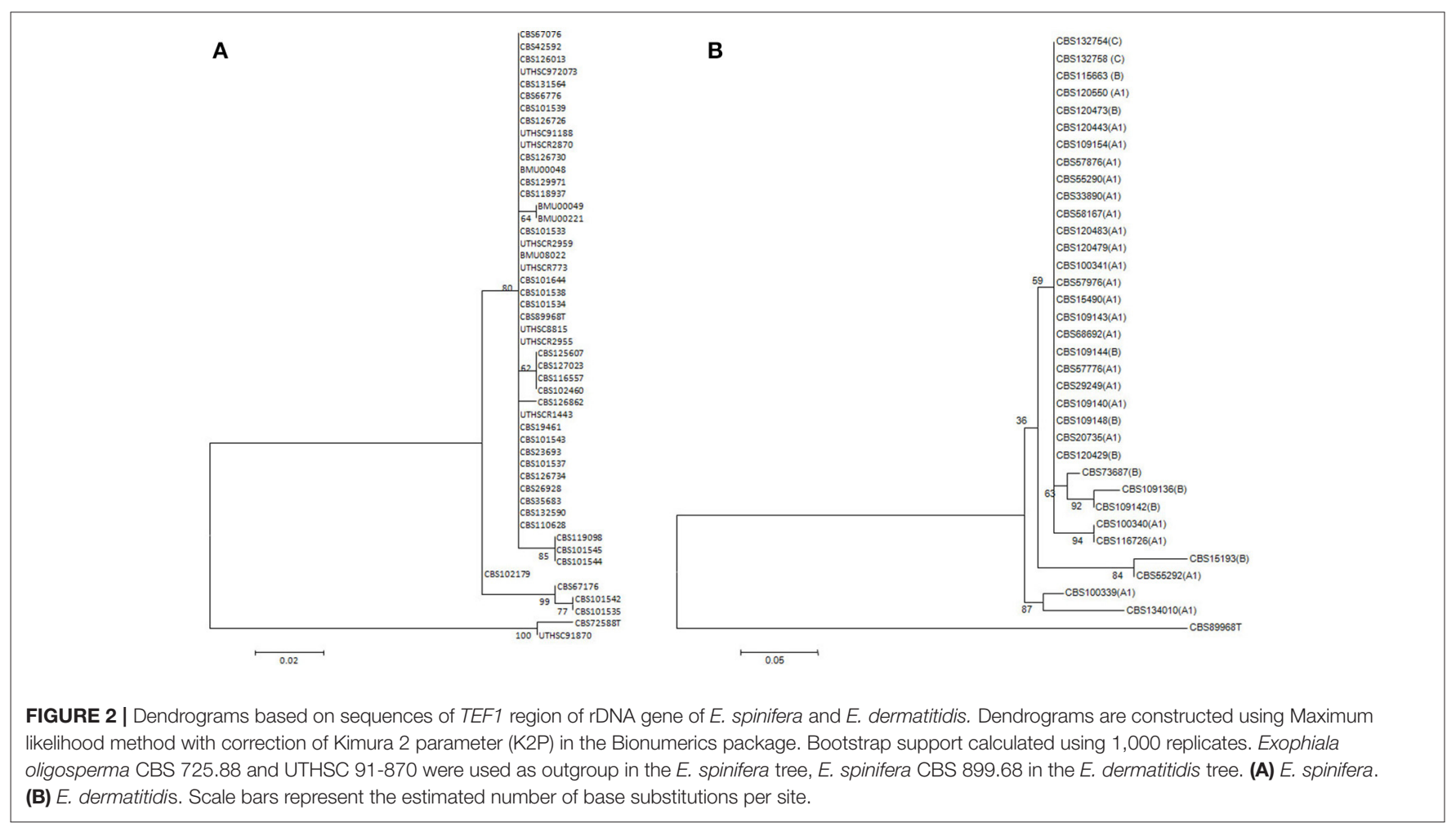


TABLE 3 | Physiological and other phenotypic test results of 20 selected strains of each species.

\begin{tabular}{|c|c|c|c|c|c|c|c|c|c|c|c|c|c|c|c|c|c|}
\hline nber & PST (mM) & $\begin{array}{l}\overline{0} \\
\text { z } \\
\text { iे }\end{array}$ & $\begin{array}{l}\overline{0} \\
z \\
\circ \\
\circ\end{array}$ & $\begin{array}{l}\text { N } \\
\sum^{\circ} \\
\text { iे }\end{array}$ & $\begin{array}{l}\text { No } \\
\sum^{\circ} \\
\stackrel{0}{\circ} \\
\stackrel{0}{0}\end{array}$ & 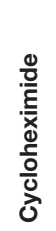 & $\begin{array}{l}\frac{n}{n} \\
\frac{2}{0} \\
\frac{20}{3}\end{array}$ & 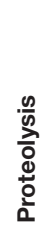 & $\begin{array}{l}\frac{00}{0} \\
\frac{0}{0} \\
\stackrel{0}{0} \\
\frac{0}{x}\end{array}$ & 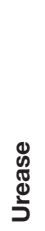 & 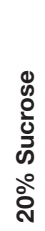 & 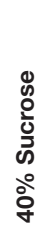 & 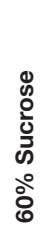 & Cell shape $24^{\circ} \mathrm{C}$ & Cell shape $37^{\circ} \mathrm{C}$ & 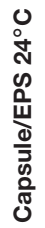 & 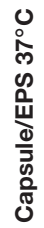 \\
\hline
\end{tabular}

\section{E. SPINIFERA}

CBS 101533

CBS 101539

CBS 116557

CBS 425.92

CBS 667.76

CBS 670.76

CBS 126013

CBS 127023

CBS126726

CBS 131564

CBS 101543

CBS 102179

CBS 119098

BMU 00048

BMU 00049

CBS 125607

CBS 129971

CBS 269.28

CBS 899.68

CBS 194.61

\section{E. DERMATITIDIS}

CBS 134010

CBS 120483

CBS 552.90

CBS 525.76

CBS 292.49

CBS 120443

CBS 120550

CBS 578.76

CBS 115663

CBS 207.35

CBS 686.92

CBS 120429

CBS 120473

CBS 120472

CBS 109144

CBS 109149

CBS 132754

CBS 123474

CBS 132758

CBS 109154

$\begin{array}{llllllllll}+ & - & + & + & ++ & + & + & - & ++ & ++ \\ + & - & + & + & ++ & + & + & + & w & ++ \\ + & - & + & + & ++ & + & + & - & + & ++ \\ + & - & + & + & ++ & + & + & - & w & ++ \\ + & - & + & + & ++ & + & + & - & ++ & ++ \\ + & - & + & + & ++ & + & + & + & - & ++ \\ + & - & + & + & ++ & + & + & + & ++ & ++ \\ + & - & + & + & ++ & + & + & + & ++ & ++ \\ + & - & + & + & ++ & + & + & + & w & ++ \\ + & - & + & + & ++ & + & + & + & ++ & ++ \\ + & - & + & + & ++ & + & + & + & ++ & ++ \\ + & - & + & + & ++ & + & + & - & ++ & ++ \\ + & - & + & + & ++ & + & + & - & ++ & ++ \\ + & + & + & + & ++ & + & + & + & - & ++ \\ + & - & + & + & ++ & + & + & - & ++ & ++ \\ + & - & + & + & ++ & + & - & + & w & ++ \\ + & - & + & + & ++ & + & + & - & - & ++ \\ + & - & + & + & ++ & + & + & - & ++ & ++ \\ + & - & + & + & ++ & + & + & - & - & ++ \\ + & - & + & + & ++ & + & + & + & ++ & ++\end{array}$

$++\quad+$

Meristematic

Meristematic

Hyphae

Meristematic

Meristematic

combination

Meristematic

Meristematic

Meristematic

Yeast

Yeast

Meristematic

Meristematic

Meristematic

Hyphae

Hyphae/Meristematic

Meristematic

Meristematic

Meristematic

$12+-\quad+\quad+\quad++\quad+\quad+\quad+\quad++\quad++\quad+\quad-$ Meristematic

$6 \quad+\quad-\quad+\quad-\quad+\quad-\quad-\quad-\quad++\quad++\quad+\quad-\quad$ Meristematic

Meristematic

Yeast

Yeast

Meristematic

Meristematic

Yeast

Yeast

Meristematic

Yeast

Yeast

very slow growth

Yeast

Meristematic

Meristematic

Yeast/Hyphae

Yeast

Meristematic

Yeast

Yeast
Meristematic

Yeast

Yeast

Yeast

Meristematic/Hyphae

Hyphae

Yeast

Yeast

Yeast

Yeast

Yeast

Yeast

Meristematic

Meristematic

Hyphae/Meristematic

Meristematic

Hyphae

Hyphae

Meristematic

Meristematic

Yeast/Hyphae

Yeast/Hyphae

Yeast

Yeast

Meristematic

Yeast

Yeast

Yeast/Hyphae

Meristematic

Yeast

Yeast

C

EPS, extracellular polysaccharide; PST, Peroxide stress tolerance (maximum concentration tolerated). W or $w$, weak positive; +, positive; ++, strong positive; -, negative. 
TABLE 4 | Polysaccharide capsule production related genes.

\begin{tabular}{|c|c|c|c|c|c|}
\hline C. neoformans-Gene ID & Name & Capsule phenotype & References & E. spinifera-Gene ID & E. dermatitidis-Gene ID \\
\hline CNAG_00268 & ILV2 & Нyро & Kingsbury et al., 2004 & PV08_11571T0 & HMPREF1120_02016T0 \\
\hline CNAG_00396 & PKA1 & Hypo & D’Souza et al., 2001 & $\mathrm{~N} / \mathrm{A}$ & $N / A$ \\
\hline CNAG_00440 & SSN801 & Hyper & Liu et al., 2008 & PV08_01597T0 & HMPREF1120_01045T0 \\
\hline CNAG_00697 & UGE1 & Hyper & Moyrand et al., 2007 & PV08_02096T0 & HMPREF1120_01443T0 \\
\hline CNAG_00721 & CAP59 & Нyро & $\begin{array}{l}\text { Chang and Kwon-Chung, 1994; Moyrand } \\
\text { and Janbon, } 2004\end{array}$ & N/A & $\mathrm{N} / \mathrm{A}$ \\
\hline CNAG_00746 & CAS35 & Нyро & Moyrand et al., 2004, 2007 & N/A & N/A \\
\hline CNAG_01523 & HOG1 & Hyper & Bahn et al., 2005 & PV08_06527T0 & HMPREF1120_05833T0 \\
\hline CNAG_01551 & GAT201 & Нypo & Liu et al., 2008 & PV08_04845T0 & HMPREF1120_00248T0 \\
\hline CNAG_01626 & $A D A 2$ & Hypo & Haynes et al., 2011 & PV08_00126T0 & HMPREF1120_06980T0 \\
\hline CNAG_01654 & CAS34 & GXM defect & Moyrand et al., 2007 & N/A & $\mathrm{N} / \mathrm{A}$ \\
\hline CNAG_01727 & SSA1 & Hyper & Zhang et al., 2006 & PV08_02973T0 & HMPREF1120_02626T0 \\
\hline CNAG_01845 & PKC1 & Нyро & Heung et al., 2005 & PV08_09341T0 & HMPREF1120_07353T0 \\
\hline CNAG_01890 & MET6 & Нyро & Pascon et al., 2004 & PV08_04416T0 & HMPREF1120_05363T0 \\
\hline CNAG_02029 & WSP1 & Нypo & Shen et al., 2011 & PV08_03067T0 & N/A \\
\hline CNAG_02153 & TUP1 & Hyper & Lee et al., 2009 & PV08_11209T0 & HMPREF1120_04775T0 \\
\hline CNAG_02215 & HAP3 & Нyро & Jung et al., 2010 & PV08_04195T0 & N/A \\
\hline CNAG_03322 & UXS1 & Xylosolation defect & Moyrand et al., 2002 & $\mathrm{~N} / \mathrm{A}$ & $\mathrm{N} / \mathrm{A}$ \\
\hline CNAG_03438 & HXT1 & Hyper & Chikamori and Fukushima, 2005 & N/A & $\mathrm{N} / \mathrm{A}$ \\
\hline CNAG_03582 & RIM20 & Нyро & ÒMeara et al., 2010b & PV08_05544T0 & HMPREF1120_02658T0 \\
\hline CNAG_03670 & IRE1 & Нyро & Cheon et al., 2011 & PV08_04820T0 & HMPREF1120_00610T0 \\
\hline CNAG_03818 & SSK1 & Hyper & Bahn et al., 2007 & PV08_04132T0 & HMPREF1120_04973T0 \\
\hline CNAG_04162 & PKA2 & Нypo & D’Souza et al., 2001 & PV08_06181T0 & HMPREF1120_06255T0 \\
\hline CNAG_04312 & MAN1 & Hypo & Wills et al., 2001 & PV08_06851T0 & HMPREF1120_08308T0 \\
\hline CNAG_04505 & GPA1 & Нyро & Alspaugh et al., 1997 & PV08_06528T0 & HMPREF1120_05834T0 \\
\hline CNAG_04730 & GPR4 & Нypo & Xue et al., 2006 & N/A & $N / A$ \\
\hline CNAG_04864 & CIR1 & Нypo & Jung et al., 2006 & PV08_09234T0 & HMPREF1120_00896T0 \\
\hline CNAG_04952 & CPS1 & Нyро & Chang et al., 2006 & PV08_07536T0 & HMPREF1120_08949T0 \\
\hline CNAG_04969 & UGD1 & Нypo & $\begin{array}{l}\text { Griffith et al., 2004; Moyrand and Janbon, } \\
2004\end{array}$ & PV08_08061T0 & HMPREF1120_03278T0 \\
\hline CNAG_05081 & PDE1 & Hyper & Hicks et al., 2005 & N/A & $\mathrm{N} / \mathrm{A}$ \\
\hline CNAG_05139 & UGT1 & Hyper & Moyrand et al., 2007 & PV08_01002TO & HMPREF1120_07559T0 \\
\hline CNAG_05218 & $A C A 1$ & Нyро & Bahn et al., 2004 & PV08_06686T0 & HMPREF1120_08701T0 \\
\hline CNAG_05222 & NRG1 & Hypo & Cramer et al., 2006 & N/A & $N / A$ \\
\hline CNAG_05431 & RIM101 & Нypo & ÒMeara et al., 2010b & PV08_06048T0 & HMPREF1120_00699T0 \\
\hline
\end{tabular}


TABLE 4 | Continued

\begin{tabular}{|c|c|c|c|c|c|}
\hline C. neoformans-Gene ID & Name & Capsule phenotype & References & E. spinifera-Gene ID & E. dermatitidis-Gene ID \\
\hline CNAG_05563 & HOS2 & Hyper & Liu et al., 2008 & $N / A$ & N/A \\
\hline CNAG_05703 & LRG1 & Hypo & Gerik et al., 2005 & PV08_01033T0 & HMPREF1120_07444T0 \\
\hline CNAG_05817 & GMT1 & Нypo & Cottrell et al., 2007 & PV08_03821T0 & HMPREF1120_04904T0 \\
\hline CNAG_06808 & CPRa & Нypo & Chang et al., 2003 & $N / A$ & $N / A$ \\
\hline CNAG_07408 & STE2O & Нypo & Wang et al., 2002 & PV08_01113T0 & HMPREF1120_05115T0 \\
\hline CNAG_07470 & PDE2 & Hyper & Hicks et al., 2005 & PV08_05494T0 & HMPREF1120_02921T0 \\
\hline CNAG_07554 & CAP10 & Нypo & $\begin{array}{l}\text { Chang and Kwon-Chung, 1999; Moyrand } \\
\text { and Janbon, } 2004\end{array}$ & PV08_06099T0 & HMPREF1120_00655T0 \\
\hline
\end{tabular}

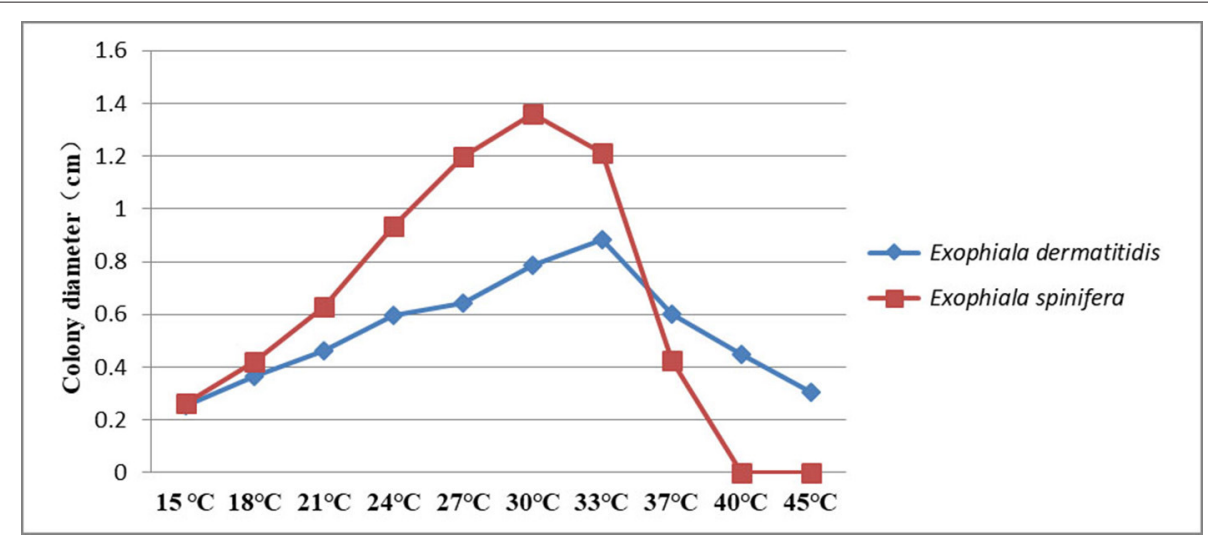

FIGURE 3 | Thermotolerance of E. spinifera and E. dermatitidis. The averaged over 20 selected strains of each species are tested.

likely to have an environmental origin. The nearest neighbor is Exophiala phaeomuriformis, which differs phenotypically by having a lower maximum growth temperature (Matos et al., 2003).

The 48 strains of E. spinifera, when sequenced for ITS, TUB and TEF1 did not show bootstrap-supported subclusters, and clustering was not concordant between genes. No consistent difference was found between clinical and environmental strains, which may indicate that the isolates from patients are likely to have an environmental origin (Figure 2). The nearest neighbor is Exophiala exophialae, represented by three strains differing in concordant ITS and TEF1 sequences.

\section{Pathogenic Traits}

Results are presented in Table 3. Both species produce extracellular slime around 5-7 day-old budding cells at $24^{\circ} \mathrm{C}$. In E. spinifera this occurs in the form of capsules of $5-6 \mu \mathrm{m}$ width, of equal dimensions in environmental and clinical strains. The EPS produced under similar conditions in E. dermatitidis was diffused. Comparative genomic analyses using E. spinifera, E. dermatitidis, and C. neoformans, a model organism for capsule studies, revealed few differences between the black yeasts. Among the 62 genes correlated with the production and regulation of the polysaccharide capsule in C. neoformans, 45 and 42 orthologous genes were found in E. spinifera and E. dermatitidis, respectively (Table 4). Contrary to E. spinifera, where homologs of the alpha glucan synthase gene (AGS1) was found, in E. dermatitidis this homolog was absent, which might lead to slower growth, sensitivity to temperature and lack of structured capsule polysaccharide on budding cell surfaces (Reese et al., 2007). In addition, homologs corresponding to WSP1, a protein with multiple functions including production of the polysaccharide capsule and secretion of the enzyme urease (Shen et al., 2011), were identified in E. spinifera but seemed to be lost in the studied strain of E. dermatitidis. 
Both species had a broad range of thermotolerance (Figure 3). E. dermatitidis has an optimum at $33^{\circ} \mathrm{C}$ and still is able to grow at $45^{\circ} \mathrm{C}$. E. spinifera has an optimum at $30^{\circ} \mathrm{C}$, while its maximum growth temperature is $40^{\circ} \mathrm{C}$. No growth is observed at $45^{\circ} \mathrm{C}$; this temperature is fungistatic as about $50 \%$ of the strains showed regrowth when placed at $24^{\circ} \mathrm{C}$.

Hemolysis remained negative in all strains of E. dermatitidis and was positive in $50 \%$ of E. spinifera strains. E. dermatitidis showed slow acidification (yellow color change) and no proteolysis on Bromocresol purple-milk solids-glucose agar

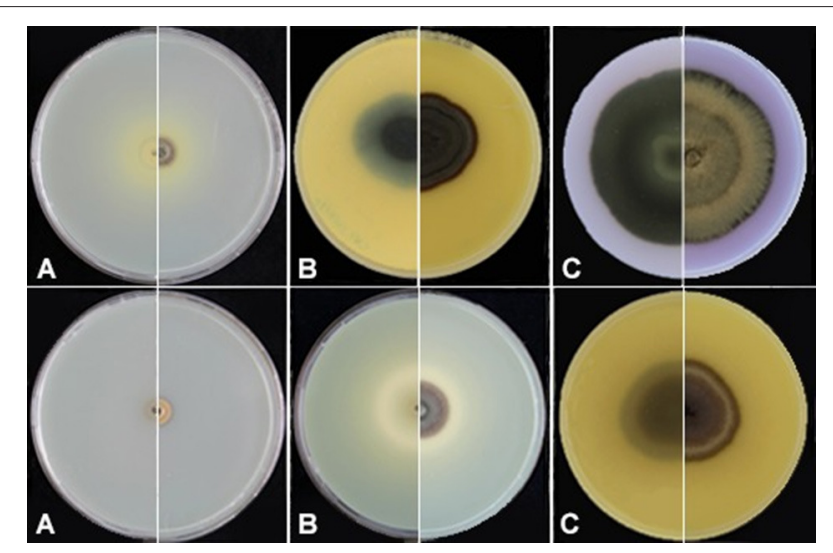

FIGURE 4 | Proteolysis of E. spinifera strain CBS 125607 (upper panel) and E. dermatitidis strain CBS 120483 (lower panel). (A) Incubation for 1 week; (B) Incubation for 2.5 weeks; (C) Incubation for 1 month.
(BCP-MS-G). E. spinifera showed acidification within 1-2 weeks followed by a change to purple (alkaline) indicating casein decomposition (Figure 4). In general, growth velocity of E. spinifera was stimulated on protein medium. Nine strains of E. spinifera showed acidification of calcium carbonate medium, while only two E. dermatitidis were positive. Urease was positive in $25 \%$ of $E$. dermatitidis strains and in $80 \%$ of E. spinifera strains. The repertory of genes associated with nitrogen metabolism is composed by a single copy of the gene coding for urease (URE1) in both E. dermatitidis and E. spinifera (Table 5). In E. dermatididis, the homolog gene of URE1 shares $86 \%$ of BLASTP identity with that of the neurotropic black fungus Rhinocladiella mackenziei. The URE1 found in E. spinifera is highly conserved among other black yeasts members of the jeanselmei-clade, including Exophiala oligosperma (94\% identity) and Exophiala xenobiotica (89\% identity).

Lipolysis was positive in all E. spinifera strains and negative in E. dermatitidis strains. Genome-wide analyses revealed an abundance of lipases in both E. dermatididis and E. spinifera. Overall, the species possess 135 and 212 putative lipases, respectively. Twenty-one lipase families are conserved among these fungi, while three families seem to be specific to E. spinifera (Figure 5). The most abundant superfamily in E. spinifera was annotated ascytosolic hydrolases (abH08), including epoxide hydrolases and haloalkane dehalogenases. In E. dermatididis, the most abundant superfamily corresponds to Moraxella lipase 2-like (abH04). The superfamily abH04 consists of three families of bacterial esterases and lipases.

TABLE 5 | Ureases and their associated genes.

\begin{tabular}{|c|c|c|c|c|c|}
\hline Gene* & Z518_04527-UreF & Z518_02869-UreD & Z518_06116-UreG & $\begin{array}{l}\text { Z518_07397-Nickel/cobalt } \\
\text { transporter, high-affinity }\end{array}$ & Z518_09873-URE1 \\
\hline E. dermatitidis & HMPREF1120_02686T0 & HMPREF1120_00803T0 & HMPREF1120_08744T0 & HMPREF1120_08266T0 & HMPREF1120_06619T0 \\
\hline
\end{tabular}

${ }^{\star}$ Reference genes extracted from R. mackenziei.

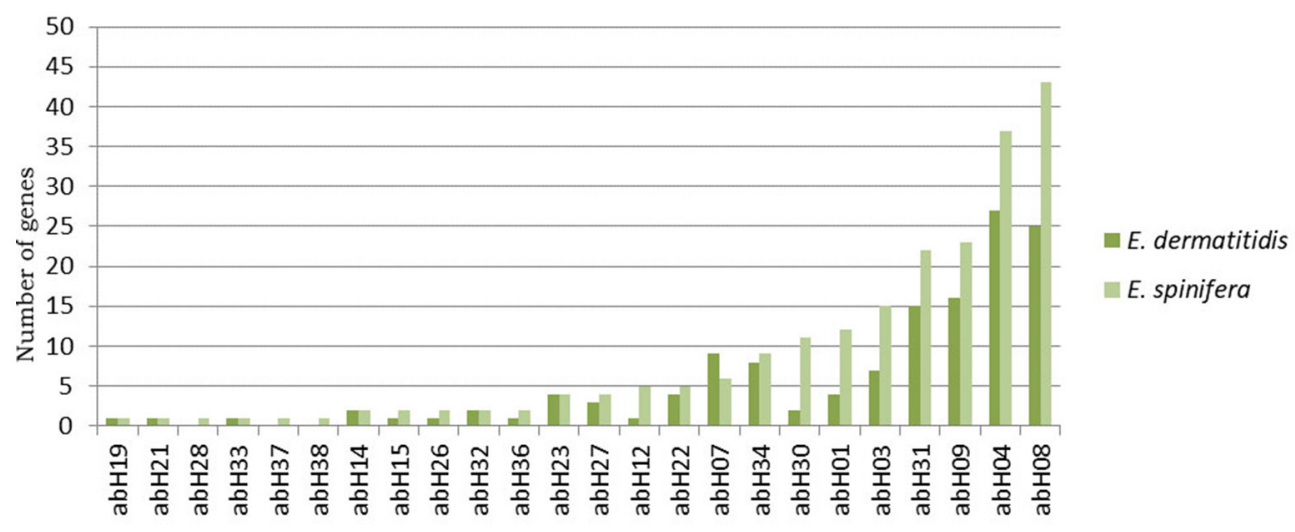

FIGURE 5 | Lipase composition in E. spinifera and E. dermatitidis. Twenty-one lipase families are conserved among these fungi, while three families seem to be specific to E. spinifera. 
TABLE 6 | Cell wall modification pathway genes.

Chitin synthase

CHS1 Class I, CHS2 class II

HMPREF1120_06816, HMPREF1120_07981

CHS3 Class III

CHS4 Class IV

CHS5 Class V, CHS7 Class VII

\section{CHS6 Class VI}

Chitin synthase like

UDP-N-acetylglucosamine 6-dehydrogenase

Regulation of chitin synthase activity, by analogy to $S$. cerevisiae

SKT5 Activator of Chs3p during vegetative growth

Similarity with ScSkt5, activator of Chs3

Similarity with ScSkt5, activator of Chs3

BNI4 scaffold protein that tethers chitin synthase III (Chs3p) to the bud neck

ScCHS5 Similarity with ScChs5, component of exomer complex

ScCHS6 Similarity with ScChs6, component of exomer complex

Similarity with export control protein ScChs7

ScCHS7 Similarity with export control protein ScChs7

Chitin modification

Cda1/2 chitin deacetylase

Chitin degradation

ChiA GPI anchored class III chitinase

Class III chitinase

ChiB Class $\vee$ chitinase

Class $\vee$ chitinase

Chitinase

Chitinase

NagA Extracellular $\mathrm{N}$-acetyl-beta-glucosaminidase

NagA

1,3-a-glucan synthesis and processing

AgsB/A Catalytic subunits of the 1,3-a-glucan synthase complex (GT5 and GH13) - http://www.cazy.org/

Putative amylase; similarity with $\mathrm{H}$. capsulatum Amy1

1,3-b-glucan synthesis and processing

FksA Putative catalytic subunit 1,3-b-glucan synthase complex; ScFks1-like

ScSMI1 Putative regulatory component 1,3-b-glucan synthesis; ScKnr4-like

EngA Endo-1,3-b-glucanase (GH 81-family); ScEng1-like

Putative exo-1,3-b-glucanase family (GH 5); related to the ScExg1-family

Putative exo-1,3-b-glucanase family (GH 55); related to Coniothyrium minitans exo-1,3-glucanase (Cmg1)

Bgl2-family of putative 1,3-b-transglucosylases (GH 17) proposed to be involved
HMPREF1120_06479

HMPREF1120_07721

HMPREF1120_08776, HMPREF1120_08777

HMPREF1120_09115

HMPREF1120_01791

HMPREF1120_01790

HMPREF1120_07720

HMPREF1120_06335

HMPREF1120_05528

HMPREF1120_05249

HMPREF1120_05359

HMPREF1120_01856

HMPREF1120_00837

HMPREF1120_03003

HMPREF1120_08023

HMPREF1120_03399

HMPREF1120_02334

HMPREF1120_06669

HMPREF1120_03714

HMPREF1120_04557

HMPREF1120_07241

HMPREF1120_06035

HMPREF1120_06285

HMPREF1120_08319

HMPREF1120_03460

HMPREF1120_03476

HMPREF1120_04893

HMPREF1120_09022

HMPREF1120_04506

HMPREF1120_06180

HMPREF1120_01556

HMPREF1120_05230

HMPREF1120_00547

HMPREF1120_05209

HMPREF1120_06595

HMPREF1120_08449

HMPREF1120_04141

HMPREF1120_03066

HMPREF1120_08078
PV08_00820,

PV08_10842

PV08_10744

PV08_01895

PV08_07002,

PV08_07003

PV08_07085

PV08_06692

PV08_01896

PV08_10210

PV08_11174

PV08_03080

PV08_04423

PV08_11343

PV08_09293

PV08_09547

PV08_03824

PV08_09305

PV08_02554

PV08_07861

PV08_03599

PV08_05624

PV08_06135

PV08_03291, PV08_03292, PV08_03826

PV08_06861

PV08_02428

PV08_10508

PV08_03822

PV08_06894

PV08_03500

PV08_06271

PV08_03602,

PV08_11776

PV08_01318 PV08_00062 PV08_10359 PV08_01193 PV08_08282

PV08_03009 PV08_10096 
TABLE 6 | Continued

Genes*: the key or differential genes in the cell wall modification pathway

Crh1-family of putative transglycosidases (GH 16);involved in crosslinking b-glucan

Gas-family of putative 1,3-b-transglucosylases (GH 72) proposed to be involved in connecting the emerging 1,3-b-glucan chains to the existing b-glucan

GelG 1,3-b-glucanosyltransferase

SunA Sun family, involved in septation, possibly b-glucosidase activity;

SunB

Kre6 Putative transglycosidase required for 1,6-b-glucan biosynthesis

CelA Similarity with cellulose synthases of the GT 2 family. Putatively involved in 1,3-b-/1,4-b-glucan synthesis

Mlg1 Mixed-linked glucanases in C. carbonum, hydrolyze 1,3-b-/1,4-b-glucans

Mlg1

Mlg1

Other cell wall biosynthesis proteins

Endo-mannanase family (GH 76) with a putative role in GPI-CWP incorporation;
E. dermatitidis $\quad$ E. spinifera

HMPREF1120_04931

PV08_03356

HMPREF1120_00627

PV08_04702

PV08_07455

PV08_05520

HMPREF1120_02703

PV08_09503

HMPREF1120_07283

PV08_11789

HMPREF1120_01763

PV08_10507

HMPREF1120_03477

PV08_11613

HMPREF1120 01682

PV08_06721

PV08_00042

HMPREF1120_06902

PV08_06798

HMPREF1120_01614

HMPREF1120_04699

HMPREF1120_05299

PV08_00315

HMPREF1120_02373

PV08_09397

HMPREF1120_07765

HMPREF1120_09051

PV08_01870

PV08_07166

HMPREF1120_04431

HMPREF1120_03513

PV08_03378

PV08_10453

PV08_11178
Both species grow well on $5 \% \mathrm{NaCl}$ or $\mathrm{MgCl}_{2}$, while E. spinifera tolerated $10 \% \mathrm{MgCl}_{2}$. No osmotolerance $(60 \%$ sucrose) was observed. Cycloheximide tolerance was noted in both species, growth of E. spinifera being better than that of E. dermatitidis. Highest degrees of tolerance, with growth on SGA with $0.2 \%$ cycloheximide at $37^{\circ} \mathrm{C}$, was observed in E. spinifera, while E. dermatitidis was somewhat inhibited. Growth at ambient temperature was with hyphae and yeast cells with a small number of isodiametrically inflating (meristematic) cells with dark and thick walls resembling muriform cells, but at $37^{\circ} \mathrm{C}$ yeast cells were preponderant. Incubated in acidic medium at 24 and $37^{\circ} \mathrm{C}$, no septate muriform cells were produced, but dark, thick-walled yeast-like cells were prevalent. Comparative analyses of the cell wall genes in E. spinifera against the previously described gene set in E. dermatitidis revealed important differences between the species. In contrast to E. dermatididis, E. spinifera possesses multiple copies of genes involved in $\alpha$-glucan metabolism (Table 6). For instance, the GT5 and GH13 genes (PV08_03291, PV08_03292, and PV08_03826), which were reported to be reduced in E. dermatitidis, were found in E. spinifera. These genes are required for the 1, 3- $\alpha$-glucan synthesis. Conversely, all seven previously described chitin synthase genes were observed in both species (Table 6).

Exophiala dermatitidis tolerated 6-9 $\mathrm{mM}$ hydrogen peroxide, while the maximum concentration allowing growth of E. spinifera was 9-12 mM. With increasing $\mathrm{H}_{2} \mathrm{O}_{2}$-concentration, morphology of colonies changed from hyphae to yeast and cell walls tended to lose melanin (Figures 6, 7 and Tables 7, 8). In both species we predicted genes coding for the bifunctional catalase/peroxidase enzymes (PV08_11368 in E. spinifera and HMPREF1120_01299 in E. dermatitidis) that may reduce hydrogen peroxide. The genes carry the functional protein domain Haem peroxidase (IPR002016). Phylogenetic analyses indicated that it belongs to Class I, which includes intracellular peroxidases involved in cellular protection against toxic peroxides (Delort et al., 1989; Figure 8).

\section{Galleria mellonella Virulence Model}

To determine if there was any difference in pathogenicity between E. dermatitidis and E. spinifera, we determined the LD50 in Galleria mellonella larvae at $37^{\circ} \mathrm{C}$. No significant difference in the LD50 values between E. dermatitidis and E. spinifera was observed. However, we did notice a difference in death rates between the species. At an inoculum of $10^{7}$ Colony Forming Units per larvae, all larvae infected with $E$. dermatitidis died before day 6, while at that time point still $30 \%$ of E. spinifera infected larvae were alive. It took till day 10 before all E. spinifera infected larvae died. This difference in time-to-death between the two species was significant (Log-Rank, $p=0.001$ ) (Figure 9). Within each species also a difference was noted between larvae infected with environmental isolates or with isolates obtained from clinical cases. The time-to-death in G. mellonella larvae infected with clinical isolates of $E$. dermatitidis was shorter than in G. mellonella larvae infected with environmental isolates of the same species (Log-Rank, $p=0.006$ ). The same was true for E. spinifera (Log-Rank, $p=0.0326)$.

\section{DISCUSSION}

Melanized fungi of the order Chaetothyriales are frequently involved in human infection; the Atlas of Clinical Fungi lists 48 clinically relevant species. Nonetheless they are regarded as opportunists, as for only very few species a natural life cycle with an animal host has been suggested (Vicente et al., 2008). 


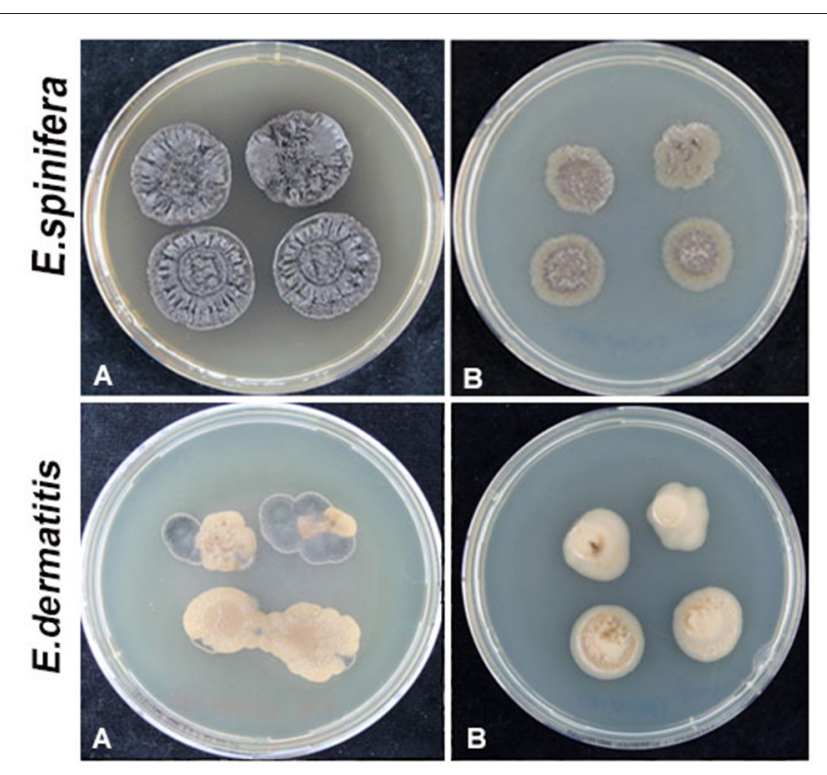

FIGURE 6 | Peroxide tolerance for E. spinifera strain CBS 101542 and E. dermatitidis strain CBS 134010. Upper panel $(\mathbf{A}, \mathbf{B})$ melanized colonies of CBS 101542 subjected to CBS 101542 peroxide; Lower panel (A,B) colonies subjected to CBS 134010 peroxide showing loss of melanin.

As opportunists, it is predicted that their invasive potential has to be explained from their environmental behavior. For example, agents of subcutaneous skin disease may be present on decaying thorns of prickly plants (Vicente et al., 2008), while hydrophilic yeast-like species can be carried by aerosols and are easily inhaled (Rath et al., 1997; Horre et al., 2004; Kondori et al., 2011). It is generally assumed that within these major categories of infection routes there is not much difference between species, the clinical course mainly being determined by portal of entrance and conditions of the host. In order to test this hypothesis, we compared two black yeast species with broad similarity in their growth form and infective ability, both being able to cause disseminated infections in immunocompetent humans. A simple overview of the literature learnt that the two species are clinically very different. E. dermatitidis is common as a pulmonary colonizer in patients with cystic fibrosis, where E. spinifera has never been observed.

The traumatic route may lead to subcutaneous infection. We found that both species tend to convert to yeast under hyperoxygen or temperature stress. Thus, mycetoma formation, as reported in Exophiala jeanselmei and exceptionally in Exophiala oligosperma, is less likely in E. dermatitidis and E. spinifera. Mycetoma grains are dense clumps of sterile hyphae which are not easily phagocytosed and provoke severe inflammation. Rather, the yeast conversion of E. dermatitidis and E. spinifera suggests potential dissemination in the bloodstream and is consistent with the clinical observation of disseminated infection.

Although both species are able to cause disseminated infections in otherwise apparently healthy hosts, E. dermatitidis regularly (36\%) shows neurotropism, whereas this has never been

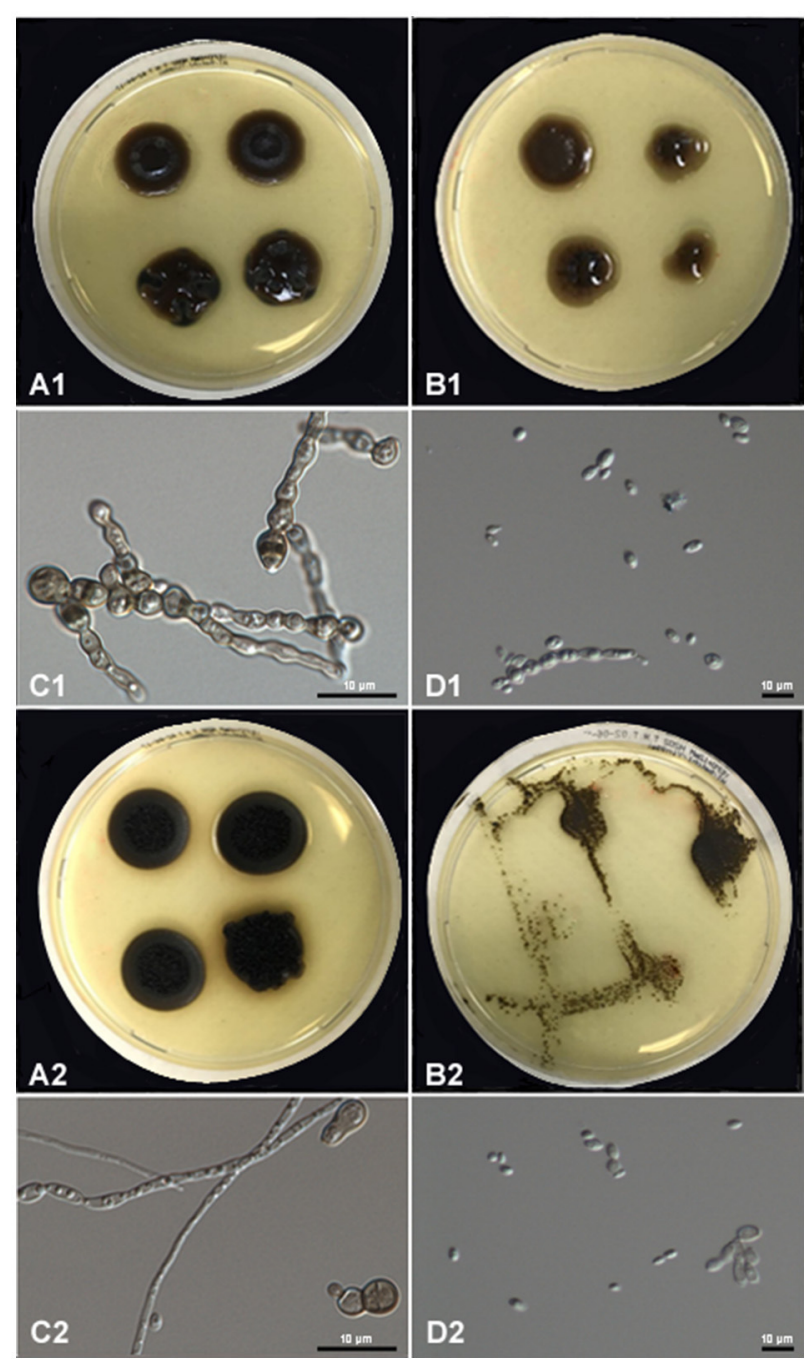

FIGURE 7 | Peroxide tolerance of E. spinifera strain CBS 116557 (upper two panels) and E. dermatitidis strain CBS 115663 (lower two panels). (A) Show mycelial phase, (B) show yeast phase, (C) show muriform cell, (D) show yeast cell.

observed in E. spinifera; in contrast, in the latter species some osteotropism (42\%) has been mentioned (Rajam et al., 1958; Campos-Takaki and Jardim, 1994; Li et al., 2011; Srinivas et al., 2016).

The habitat choice of each fungus should explain observed types of opportunism on the human host (Vicente et al., 2008; Dogen et al., 2013b; Gumral et al., 2014). Our strain data show that the ecological differences between E. spinifera and E. dermatitidis are large. E. dermatitidis is found in habitats that are either toxic or poor in nutrients, suggesting evasion of microbial competition as a strategy of the fungus. In contrast, habitat choices of E. spinifera suggest some osmophily, while its regular presence on decaying scales of coconuts-a substrate exceptionally rich in black yeasts but where E. dermatitidis remained absent-was remarkable. Babassu coconut scales are rich in fatty acids and etheric oils; the relative abundance 
TABLE 7 | The assimilation responses of 40 strains to different compounds.

\begin{tabular}{|c|c|c|c|c|c|c|c|c|c|}
\hline No. & CBS number & Hydrogen peroxide & Tween-80 & Calcium carbonate & Urea & Sucrose & Sodium & Cycloheximide & Casein \\
\hline \multicolumn{10}{|c|}{ E. DERMATITIDIS } \\
\hline 1 & CBS134010 & + & - & - & + & + & + & + & - \\
\hline 2 & CBS 120483 & + & - & + & - & + & + & + & - \\
\hline 3 & CBS 552,90 & + & - & - & - & + & + & + & - \\
\hline 4 & CBS207.35 & + & - & - & - & + & + & + & - \\
\hline 7 & CBS 120443 & + & - & - & - & + & + & + & - \\
\hline 8 & CBS 120550 & + & - & - & - & + & + & + & - \\
\hline 9 & CBS 578,76 & + & - & - & - & + & + & + & - \\
\hline 10 & CBS115663 & + & - & - & - & + & + & + & - \\
\hline 15 & CBS 109144 & + & - & - & + & + & + & + & - \\
\hline 16 & CBS 109149 & + & - & - & - & + & + & + & - \\
\hline 17 & CBS 132754 & + & - & - & - & + & + & + & - \\
\hline 18 & CBS 123474 & + & - & - & - & + & + & + & - \\
\hline 19 & CBS 132758 & + & - & - & - & + & + & + & - \\
\hline 20 & CBS 109154 & + & - & - & - & + & + & + & - \\
\hline \multicolumn{10}{|c|}{ E. SPINIFERA } \\
\hline 1 & CBS 101533 & + & + & + & + & + & + & + & + \\
\hline 2 & CBS 101539 & + & + & + & + & + & + & + & + \\
\hline 3 & CBS 116557 & + & + & + & + & + & + & + & + \\
\hline 10 & CBS 131564 & + & + & - & + & + & + & + & + \\
\hline 11 & CBS 101543 & + & + & - & + & + & + & + & + \\
\hline 12 & CBS 102179 & + & + & + & + & + & + & + & + \\
\hline 13 & CBS 119098 & + & + & - & + & + & + & + & + \\
\hline 14 & CBS 123468 & + & + & - & + & + & + & + & + \\
\hline 15 & CBS 123469 & + & + & - & - & + & + & + & + \\
\hline 16 & CBS 125607 & + & + & + & + & + & + & + & + \\
\hline 17 & CBS 129971 & + & + & + & + & + & + & + & + \\
\hline 18 & CBS 269.28 & + & + & - & - & + & + & + & + \\
\hline 19 & CBS 899.68 & + & + & + & + & + & + & + & + \\
\hline 20 & CBS 194.61 & + & + & - & - & + & + & + & + \\
\hline
\end{tabular}

+ , positive; -, negative.

of lipase genes in E. spinifera is consistent with this habitat choice. E. dermatitidis is highly selected by hot and moist indoor facilities, particularly steam baths and dishwashers, where temperatures periodically are $60-90^{\circ} \mathrm{C}$. Exophiala spinifera has not been observed in domestic environments, which not only indicates differences in ecological preference, but also in exposition to human hosts, e.g., inhalation by patients with cystic fibrosis.

In general E. spinifera was physiologically more active, as judged from its response to proteins, lipids, ureum, and acid 
production. The repertoire of protease families in E. spinifera and E. dermatitidis according to MEROPS classification (Teixeira et al., 2017) revealed striking protease family expansions in E. spinifera, such as the families M38, S09X and S33. These expansions are absent in $E$. dermatitidis and might be responsible for the differences in the protein degradation profile. Abundance of proteases at the expense of carbohydrate-active enzymes is often taken as an indication of vertebrate pathogenicity (El Kaoutari et al., 2013). Exophiala spinifera possesses multiple

TABLE 8 | Responses of 20 strains of $E$. spinifera and 20 of $E$. dermatitidis upon peroxide challenge.

\begin{tabular}{|c|c|c|c|c|}
\hline $\begin{array}{l}\text { No. of strains at max. concentration } \\
\text { tolerated }\end{array}$ & $3 \mathrm{mM}$ & $6 \mathrm{mM}$ & $9 \mathrm{mM}$ & $12 \mathrm{mM}$ \\
\hline E. spinifera & 0 & 1 & 10 & 9 \\
\hline E. dermatitidis & 1 & 10 & 9 & 0 \\
\hline $\begin{array}{l}\text { Yeast conversion at max. } \\
\text { concentration }\end{array}$ & & + & & - \\
\hline E. spinifera & & 11 & & 9 \\
\hline E. dermatitidis & & 16 & & 4 \\
\hline Melanization at max. concentration & & + & & - \\
\hline Exophiala spinifera & & 15 & & 5 \\
\hline Exophiala dermatitidis & & 4 & & 16 \\
\hline
\end{tabular}

+, positive; -, negative. copies of genes involved in $\alpha$-glucan metabolism, which is considered an essential virulence factor in chromoblastomycosis (Teixeira et al., 2017). Nonetheless the LD50 of E. spinifera was comparable to that of E. dermatitidis in the Galleria model, indicating no obvious difference in virulence between the two species. However, when larvae were infected with E. spinifera the time-to-death was prolonged compared to larvae infected with $E$. dermatitidis, indicating that at least in $G$. mellonella larvae E. spinifera was more virulent. Furthermore, the origin of the isolates appeared also to be important. In

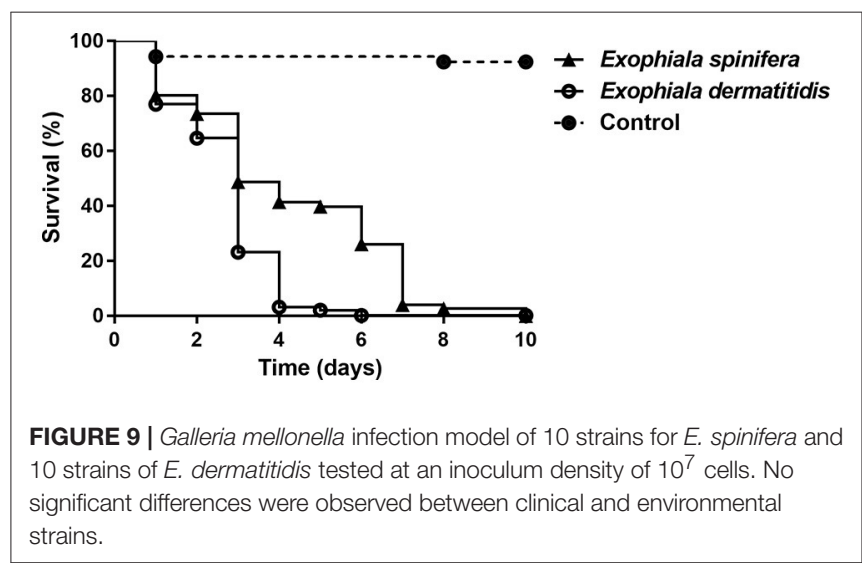

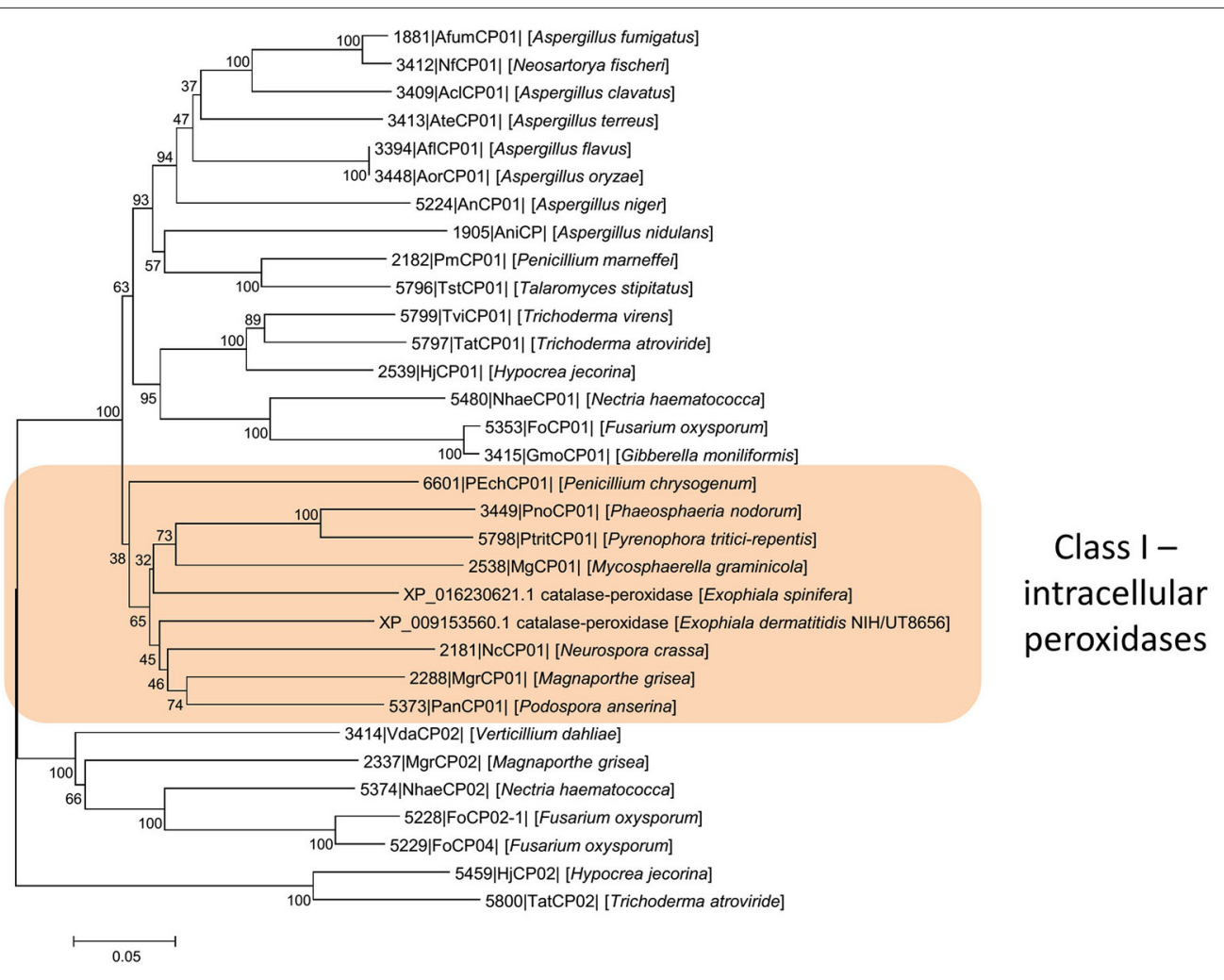

FIGURE 8 | Phylogenetic analysis of intracellular peroxidases. The analysis indicates that they belong to Class I, which includes intracellular peroxidases involved in cellular protection against toxic peroxides. Scale bars represent the estimated number of base substitutions per site. 
both E. dermatitidis and E. spinifera, a shorter time-to-death was obtained with clinical isolates compared to environmental isolates.

The species also showed more tolerance to cycloheximide and hydrogen peroxide. The response of both species to elevated oxygenic action was mostly by yeast conversion (Figure 7, Table 3) and loss of melanin (Figure 6, Table 8) rather than by the formation of muriform cells and melanization. This response is not in line with the expected pattern in agents of chromoblastomycosis. We therefore consider published cases of human chromoblastomycosis by $E$. dermatitidis or E. spinifera (Rajam et al., 1958; Li et al., 2011; Lanternier et al., 2015; Srinivas et al., 2016) as questionable. E. dermatitidis shows a higher degree of thermotolerance, as expressed in its prevalence in hot indoor wet cells. Temperatures in steam baths and dishwashers intermittently are far above the permissive temperature for growth. Tesei et al. (2015) demonstrated that the fungus upon hostile conditions turns down its metabolism rather than showing a physiological stress response, which might be a survival mechanism for the superextreme. It is speculated that E. spinifera lacks this strategy, as it has never been isolated from indoor habitats with extreme temperatures.

In E. spinifera, two patient populations have been described, i.e., healthy children and adolescents on the one hand, and elderly patients on the other. Somewhat unexpectedly, the former group was associated with fatal disseminated infection, whereas the latter only developed mild disease with successful cure. In contrast, dissemination in E. dermatitidis mostly occurred in East-Asian immunocompetent patients, and involvement of cervical lymph nodes and central nervous system was frequently reported. The species has a global distribution in the domesticated environment (Sudhadham et al., 2008), and therefore it remains unexplained why this type of infection is nearly limited to East Asia.

In both species investigated, molecular diversity has been reported. E. dermatitidis has several ITS-based genotypes, but our study demonstrated that ribosomal variation did not correspond with variation in protein-coding genes, and thus the species can be regarded as a single biological entity, clearly separated from its nearest neighbor species E. phaeomuriformis. E. spinifera showed a nearly identical degree of intraspecific variation; only the distinction of a small cluster known as E. exophialae was supported in all partitions, confirming this group as a neighboring species. This led to the conclusion that E. dermatitidis and E. spinifera cannot be meaningfully subdivided, and no lineages with reduced gene flow seem to exist. The found degrees of variation in barcoding genes (ITS Hd $=0.76$ and 0.71 in E. spinifera and E. dermatitidis, respectively) may be taken as a model for black yeasts. No ascosporulating sexual states have been observed in either of them-although non-sporulating fruiting bodies have been reported (Gueidan et al., 2008) in E. dermatitidis, and in both species only a single mating type (MAT1-2) has been observed (Teixeira et al., 2017), thus possibly propagation and evolution is largely by independent clones. All data indicate that variation in both species is limited to the strain level, and no predictive grouping is possible.

Strain-level variation did not show significant correlation between clinical and environmental origins. Phenotypic intraspecific variation was found e.g., in protease, urease and acid production, but none of these parameters could be linked (Table 3). Antifungal susceptibility shows some variability in both species (Badali et al., 2012), and this could not be linked to other types of variation either. Given the rather significant variation in susceptibility, it is recommended always to perform in vitro prior to therapy.

It is safe to say that neither species behaves as a human pathogen, i.e., having enhanced fitness by the use of human vectors. Rather, human infection is extremely coincidental, not playing a role in the evolution of the fungi, and therefore typically opportunistic in nature. However, our data show that even related opportunists sharing essential virulence factors in yeast phases and capsular budding cells may be clinically very different. Surprisingly, the majority of cases of both species occurred in patients without known immune disorder, and the frequency of black yeast infection does not seem to increase with growing populations of compromised patients. Possibly several of the disseminated cases were patients with hidden congenital immune defects such as CARD9 deficiency (Lanternier et al., 2015). Idiopathic invasive fungal infections should lead to a search for underlying inborn errors of immunity (Alcais et al., 2010; Casanova and Abel, 2013; Lanternier et al., 2015), but also to different sources of exposition and windows of opportunity for microbial growth.

\section{AUTHOR CONTRIBUTIONS}

YS carried out the literature search, strains collection, DNA extraction and sequencing, phylogenetic tree construction, physiology tests, Galleria mellonella virulence experiments, participated in the data analysis and drafted the manuscript. WL-vdS carried out the design of Galleria mellonella experiment and participated in the data analysis. LM carried out the genome data analysis and interpretation. BG participated in the data interpretation and analysis. RL and SdH participated in the design of the study, statistical analysis and manuscript revision and review. All authors read and approved the manuscript.

\section{FUNDING}

This work was supported by the international Cooperation and Exchanges Project (NSFC No. 81520108026) from National Natural Science Foundation of China.

\section{ACKNOWLEDGMENTS}

We acknowledge Mickey Konings from Erasmus MC, University of Rotterdam for his work on the larvae experiment. 


\section{REFERENCES}

Alabaz, D., Kibar, F., Arikan, S., Sancak, B., Celik, U., Aksaray, N., et al. (2009). Systemic phaeohyphomycosis due to Exophiala (Wangiella) in an immunocompetent child. Med. Mycol. 47, 653-657. doi: 10.1080/13693780802715815

Alcais, A., Quintana-Murci, L., Thaler, D. S., Schurr, E., Abel, L., and Casanova, J. L. (2010). Life-threatening infectious diseases of childhood: single-gene inborn errors of immunity? Ann. N.Y. Acad. Sci. 1214, 18-33. doi: $10.1111 / j .1749-6632.2010 .05834 . x$

Alspaugh, J., Perfect, J., and Heitman, J. (1997). Cryptococcus neoformans mating and virulence are regulated by the G-protein alpha subunit GPA1 and cAMP. Genes Dev. 11, 3206-3217.

Alspaugh, J., Pukkila-Worley, R., Harashima, T., Cavallo, L., Funnell, D., Cox, G., et al. (2002). Adenylyl cyclase functions downstream of the G-alpha protein Gpal and controls mating and pathogenicity of Cryptococcus neoformans. Eukaryot. Cell. 1, 75-84. doi: 10.1128/EC.1.1.75-84.2002

Badali, H., Chander, J., Bayat, M., Seyedmousavi, S., Sidhu, S., Rani, H., et al. (2012). Multiple subcutaneous cysts due to Exophiala spinifera in an immunocompetent patient. Med. Mycol. 50, 207-213. doi: $10.3109 / 13693786.2011 .603367$

Bahn, Y., Hicks, J., Giles, S., Cox, G., and Heitman, J. (2004). Adenylyl cyclaseassociated protein AcaI regulates virulence and differentiation of Cryptococcus neoformans via the cyclic AMP-protein kinase a cascade. Eukaryot. Cell. 3, 1476-1491. doi: 10.1128/EC.3.6.1476-1491.2004

Bahn, Y., Kojima, K., Cox, G., and Heitman, J. (2005). Specialization of the HOG pathway and its impact on differentiation and virulence of Cryptococcus neoformans. Mol. Biol. Cell. 16, 2285-2300. doi: 10.1091/mbc.E04-11-0987

Bahn, Y.-S., Geunes-Boyer, S., and Heitman, J. (2007). Ssk2 mitogen-activated protein kinase kinase kinase governs divergent patterns of the stress activated Hog1 signaling pathway in Cryptococcus neoformans. Eukaryot. Cell 6, 2278-2289. doi: 10.1128/EC.00349-07

Baker, L. G., Specht, C. A., Donlin, M. J., and Lodge, J. K. (2007). Chitosan, the deacetylated form of chitin, is necessary for cell wall integrity in Cryptococcus neoformans. Eukaryot. Cell 6, 855-867. doi: 10.1128/EC.00399-06

Banks, I. R., Specht, C. A., Donlin, M. J., Gerik, K. J., Levitz, S. M., and Lodge, J. K. (2005). A chitin synthase and its regulator protein are critical for chitosan production and growth of the fungal pathogen Cryptococcus neoformans. Eukaryot. Cell 4, 1902-1912. doi: 10.1128/EC.4.11.1902-1912.2005

Barba-Gomez, J. F., Mayorga, J., McGinnis, M. R., and Gonzalez-Mendoza, A. (1992). Chromoblastomycosis caused by Exophiala spinifera. J. Am. Acad. Dermatol. 26, 367-370.

Barth, S., Fischer, M., Schmid, R. D., and Pleiss, J. (2004). The database of epoxide hydrolases and haloalkane dehalogenases: one structure, many functions. Bioinformatics 20, 2845-2847. doi: 10.1093/bioinformatics/bth284

Baubion, E., Desbois, N., Durox, H., Riaux, A., Deschamp, L., Derancourt, C., et al. (2008). Ulcerated nodular lesions on extremities of patient undergoing treatment for glioblastoma on French Caribbean island of Martinique. Med. Trop. 68, 537-540.

Bohelay, G., Robert, S., Bouges-Michel, C., Gerin, M., Levy, A., Fain, O., et al. (2016). Subcutaneous phaeohyphomycosis caused by Exophiala spinifera in a European patient with lymphoma: a rare occurrence case report and literature review. Mycoses 59, 691-696. doi: 10.1111/myc. 12515

Campos-Takaki, G. M., and Jardim, M. L. (1994). Report of chronic subcutaneous abscesses caused by Exophiala spinifera. Mycopathologia 127, 73-76.

Carlini, C. R., and Ligabue-Braun, R. (2016). Ureases as multifunctional toxic proteins: a review. Toxicon 110, 90-109. doi: 10.1016/j.toxicon.2015.11.020

Casanova, J. L., and Abel, L. (2013). The genetic theory of infectious diseases: a brief history and selected illustrations. Annu. Rev. Genom. Hum. Genet. 14, 215-243. doi: 10.1146/annurev-genom-091212-153448

Chang, Y. C., and Kwon-Chung, K. J. (1994). Complementation of a capsuledeficient mutation of Cryptococcus neoformans restores its virulence. Mol. Cell Biol. 14, 4912-4919.

Chang, Y. C., and Kwon-Chung, K. J. (1998). Isolation of the third capsuleassociated gene, CAP60, required for virulence in Cryptococcus neoformans. Infect. Immun. 5, 2230-2236.

Chang, Y. C., and Kwon-Chung, K. J. (1999). Isolation, characterization, and localization of a capsule-associated gene, CAP10, of Cryptococcus neoformans. J. Bacteriol. 18, 5636-5643.
Chang, Y. C., Jong, A., Huang, S., Zerfas, P., and Kwon-Chung, K. J. (2006). CPS1, a homolog of the Streptococcus pneumoniae type 3 polysaccharide synthase gene, is important for the pathobiology of Cryptococcus neoformans. Infect. Immun. 74, 3930-3938. doi: 10.1128/IAI.00089-06

Chang, Y. C., Miller, G. F., and Kwon-Chung, K. J. (2003). Importance of a developmentally regulated pheromone receptor of Cryptococcus neoformans for virulence. Infect. Immun. 71, 4953-4960. doi: 10.1128/IAI.71.9.4953-49 60.2003

Chang, Y. C., Penoyer, L. A., and Kwon-Chung, K. J. (1996). The second capsule gene of Cryptococcus neoformans, CAP64, is essential for virulence. Infect. Immun. 64, 1977-1983.

Chen, M., Zhang, J., Dong, Z., and Wang, F. (2016). Cutaneous phaeohyphomycosis caused by Exophiala dermatitidis: a case report and literature review. Indian J. Dermatol. Venereol. Leprol. 82, 173-177. doi: 10.4103/0378-6323.171013

Cheon, S. A., Jung Chen, K.-W., Heitman, Y.-L. J., Bahn, Y.-S., and Kang, H. A. (2011). Unique evolution of the UPR pathway with a novel bZIP transcription factor, Hxl1, for controlling pathogenicity of Cryptococcus neoformans. PLoS Pathog. 7:e1002177. doi: 10.1371/journal.ppat.1002177.

Chikamori, M., and Fukushima, K. (2005). A new hexose transporter from Cryptococcus neoformans: molecular cloning and structural and functional characterization. Fungal Genet. Biol. 42, 646-655. doi: 10.1016/j.fgb.2005.04.004

Chotirmall, S. H., and McElvaney, N. G. (2014). Fungi in the cystic fibrosis lung: bystanders or pathogens? Int. J. Biochem. Cell Biol. 52, 161-173. doi: 10.1016/j.biocel.2014.03.001

Cottrell, T. R., Griffith, C. L., Liu, H., Nenninger, A. A., and Doering, T. L. (2007). The pathogenic fungus Cryptococcus neoformans expresses two functional GDP-mannose transporters with distinct expression patterns and roles in capsule synthesis. Eukaryot. Cell 6, 776-785. doi: 10.1128/EC. 00015-07

Cramer, K. L., Gerrald, Q. D., Nichols, C. B., Price, M. S., and Alspaugh, J. A. (2006). Transcription factor Nrg1 mediates capsule formation, stress response, and pathogenesis in Cryptococcus neoformans. Eukaryot. Cell 5, 1147-1156. doi: 10.1128/EC.00145-06

Crosby, J. H., O'Quinn, M. H., Steele, J. C. Jr., and Rao, R. N. (1989). Fineneedle aspiration of subcutaneous phaeohyphomycosis caused by Wangiella dermatitidis. Diagn. Cytopathol. 5, 293-297.

Daboit, T. C., Duquia, R. P., Magagnin, C. M., Mendes, S. D., Castrillon, M. R., Steglich, R., et al. (2012). A case of Exophiala spinifera infection in Southern Brazil: molecular identification and antifungal susceptibility. Med. Mycol. 1, 72-75. doi: 10.1016/j.mmcr.2012.08.006

de Hoog, G. S., Matos, T., Sudhadham, M., Luijsterburg, K. F., and Haase, G. (2005). Intestinal prevalence of the neurotropic black yeast Exophiala (Wangiella) dermatitidis in healthy and impaired individuals. Mycoses 48, 142-145. doi: 10.1111/j.1439-0507.2004.01083.x

de Hoog, G. S., Poonwan, N., and Gerrits van den Ende, A. H. G. (1999). Taxonomy and pathogenicity of Exophiala spinifera and its relationship to E. jeanselmei. Stud. Mycol. 43, 133-142.

De Hoog, G. S., Queiroz-Telles, F., Haase, G., Fernandez-Zeppenfeldt, G., Attili Angelis, D., Gerrits Van Den Ende, A. H., et al. (2000a). Black fungi: clinical and pathogenic approaches. Med. Mycol. 38(Suppl. 1), 243-250. doi: 10.1080/mmy.38.s1.243.250

De Hoog, G. S., Guarro, J., Figueras, M. J., and Gené, J. (2000b). Atlas of Clinical Fungi, 2nd, Edn. Baarn; Reus: Centraalbureau voor Schimmelcultures; Universitat Rovira I Virgili.

de Hoog, G. S., Vicente, V. A., Najafzadeh, M. J., Harrak, M. J., Badali, H., and Seyedmousavi, S. (2011). Waterborne Exophiala species causing disease in cold-blooded animals. Persoonia 27, 46-72. doi: 10.3767/003158511X 614258

Delort, J., Dumas, J. B., Darmon, M. C., and Mallet, J. (1989). An efficient strategy for cloning $5^{\prime}$ extremities of rare transcripts permits isolation of multiple $5^{\prime}$ untranslated regions of rat tryptophan hydroxylase mRNA. Nucleic. Acids Res. $17,6439-6448$.

Develoux, M., Dieng, M. T., Ndiaye, B., Raphenon, G., and Lepers, J. P. (2006). Chromomycosis caused by Exophilia spinifera in Sahelian Africa. Ann. Dermatol. Vener. 133, 68-69.

Dogen, A., Kaplan, E., Ilkit, M., and de Hoog, G. S. (2013a). Massive contamination of Exophiala dermatitidis and E. phaeomuriformis in 
railway stations in subtropical Turkey. Mycopathologia 175, 381-386. doi: 10.1007/s11046-012-9594-Z

Dogen, A., Kaplan, E., Oksuz, Z., Serin, M. S., Ilkit, M., and de Hoog, G. S. (2013b). Dishwashers are a major source of human opportunistic yeast-like fungi in indoor environments in Mersin, Turkey. Med. Mycol. 51, 493-498. doi: 10.3109/13693786.2012.738313

D’Souza, C. A., Alspaugh, J. A., Yue, C., Harashima, T., Cox, G. M., Perfect, J. R., et al. (2001). Cyclic AMP-dependent protein kinase controls virulence of the fungal pathogen Cryptococcus neoformans. Mol. Cell Biol. 9, 3179-3191. doi: 10.1128/MCB.21.9.3179-3191.2001

Dutriaux, C., Saint-Cyr, I., Desbois, N., Cales-Quist, D., Diedhou, A., and BoisseauGarsaud, A. M. (2005). Subcutaneous phaeohyphomycosis due to Exophiala spinifera in a renal transplant recipient. Ann. Dermatol. Venereol. 132, 259-262.

El Kaoutari, A., Armougom, F., Gordon, J. I., Raoult, D., and Henrissat, B. (2013). The abundance and variety of carbohydrate-active enzymes in the human gut microbiota. Nat. Rev. Microbiol. 11, 497-504. doi: 10.1038/nrmicro3050

Erickson, T., Liu, L., Gueyikian, A., Zhu, X., Gibbons, J., and Williamson, P. R. (2001). Multiple virulence factors of Cryptococcus neoformans are dependent on VPH1. Mol. Microbiol. 42, 1121-1131. doi: 10.1046/j.1365-2958.2001.02712.x

Fawal, N., Li, Q., Savelli, B., Brette, M., Passaia, G., Fabre, M., et al. (2013). PeroxiBase: a database for large-scale evolutionary analysis of peroxidases. Nucleic. Acids Res. 41, D441-D444. doi: 10.1093/nar/gks1083

Fischer, J. B., and Kane, J. (1971). The detection of contamination in Trichophyton rubrum and Trichophyton mentagrophytes. Mycopathologia 43, 169-180.

Fothergill, A. W., Rinaldi, M. G., and Sutton, D. A. (2009). Antifungal susceptibility testing of Exophiala spp.: a head-to-head comparison of amphotericin B, itraconazole, posaconazole and voriconazole. Med. Mycol. 47, 41-43. doi: 10.1080/13693780802512451

Gerik, K. J., Donlin, M. J., Soto, C. E., Banks, A. M., Banks, I. R., Maligie, M. A., et al. (2005). Cell wall integrity is dependent on the PKC1 signal transduction pathway in Cryptococcus neoformans. Mol. Microbiol. 58, 393-408. doi: 10.1111/j.1365-2958.2005.04843.x

Gish, S. R., Maier, E. J., Haynes, B. C., Santiago-Tirado, F. H., Srikanta, D. L., Ma, C. Z., et al. (2016). Computational analysis reveals a key regulator of cryptococcal virulence and determinant of host response. mBio 7, e00313e00316. doi: 10.1128/mBio.00313-16

Gostincar, C., Lenassi, M., Gunde-Cimerman, N., and Plemenitas, A. (2011). Fungal adaptation to extremely high salt concentrations. Adv. Appl. Microbiol. 77, 71-96. doi: 10.1016/B978-0-12-387044-5.00003-0

Griffith, C. L., Klutts, J. S., Zhang, L., Levery, S. B., and Doering, T. L. (2004). UDPglucose dehydrogenase plays multiple roles in the biology of the pathogenic fungus Cryptococcus neoformans. J. Biol. Chem. 279, 51669-51676. doi: 10.1074/jbc.M408889200

Gueidan, C., Villaseñor, C. R., de Hoog, G. S., Gorbushina, A. A., Untereiner, W. A., and Lutzoni, F. (2008). A rock-inhabiting ancestor for mutualistic and pathogen-rich fungal lineages. Stud. Mycol. 61, 11-19. doi: $10.3114 / \operatorname{sim} .2008 .61 .11$

Gümral, R., Özhak-Baysan, B., Tümgör, A., Saraçli, M. A., Yildiran, S. T., Ilkit, M., et al. (2015). Dishwashers provide a selective extreme environment for human-opportunistic yeast-like fungi. Fungal Divers 76, 1-9. doi: 10.1007/s13225-015-0327-8

Gumral, R., Tumgor, A., Saracli, M. A., Yildiran, S. T., Ilkit, M., and de Hoog, G. S. (2014). Black yeast diversity on creosoted railway sleepers changes with ambient climatic conditions. Microb. Ecol. 68, 699-707. doi: 10.1007/s00248-014-0459-5

Harris, J. E., Sutton, D. A., Rubin, A., Wickes, B., De Hoog, G. S., and Kovarik, C. (2009). Exophiala spinifera as a cause of cutaneous phaeohyphomycosis: case study and review of the literature. Med. Mycol. 47, 87-93. doi: 10.1080/13693780802412611

Haynes, B. C., Skowyra, M. L., Spencer, S. J., Gish, S. R., Williams, M., Held, E. P., et al. (2011). Toward an integrated model of capsule regulation in Cryptococcus neoformans. PLoS Pathog. 12:e1002411. doi: 10.1371/journal.ppat.1002411

Heung, L. J., Kaiser, A. E., Luberto, C., and Del Poeta, M. (2005). The role and mechanism of diacylglycerol-protein kinase $\mathrm{Cl}$ signaling in melanogenesis by Cryptococcus neoformans. J. Biol. Chem. 280, 28547-28555. doi: 10.1074/jbc.M503404200

Hicks, J. K., Bahn, Y.-S., and Heitman, J. (2005). Pdel phosphodiesterase modulates cyclic AMP levels through a protein kinase A-mediated negative feedback loop in Cryptococcus neoformans. Eukaryot. Cell 4, 1971-1981. doi: 10.1128/EC.4.12.1971-1981.2005

Hiruma, M., Kawada, A., Ohata, H., Ohnishi, Y., Takahashi, H., Yamazaki, M., et al. (1993). Systemic phaeohyphomycosis caused by Exophiala dermatitidis. Mycoses 36, 1-7.

Horre, R., Schaal, K. P., Siekmeier, R., Sterzik, B., de Hoog, G. S., and Schnitzler, N. (2004). Isolation of fungi, especially Exophiala dermatitidis, in patients suffering from cystic fibrosis. A prospective study. Respiration 71, 360-366. doi: $10.1159 / 000079640$

Hu, B., Li, S., Hu, H., Chen, T., Guo, X., Zhang, Z., et al. (2014). Central nervous system infection caused by Exophiala dermatitidis in a case and literature review. Zhonghua er ke za zhi 52, 620-624.

Janbon, G., Himmelreich, U., Moyrand, F., Improvisi, L., and Dromer, F. (2001). Caslp is a membrane protein necessary for the O-acetylation of the Cryptococcus neoformans capsular polysaccharide. Mol. Microbiol. 42, 453-467. doi: 10.1046/j.1365-2958.2001.02651.x

Jung, W. H., Saikia, S., Hu, G., Wang, J., Fung, C. K., D’Souza, C., et al. (2010). HapX positively and negatively regulates the transcriptional response to iron deprivation in Cryptococcus neoformans. PLoS Pathog. 6:e1001209. doi: 10.1371/journal.ppat.1001209

Jung, W. H., Sham, A., White, R., and Kronstad, J. W. (2006). Iron regulation of the major virulence factors in the AIDS-associated pathogen Cryptococcus neoformans. PLoS Biol. 4:e410. doi: 10.1371/journal.pbio.0040410

Kantarcioglu, A. S., and de Hoog, G. S. (2004). Infections of the central nervous system by melanized fungi: a review of cases presented between 1999 and 2004 Mycoses 47, 4-13.

Karuppayil, S. M., and Szaniszlo, P. J. (1997). Importance of calcium to the regulation of polymorphism in Wangiella (Exophiala) dermatitidis. J. Med. Vet. Mycol. 35, 379-388.

Kingsbury, J. M., Yang, Z., Ganous, T. M., Cox, G. M., and McCusker, J. H. (2004). Cryptococcus neoformans Ilv2p confers resistance to sulfometuron methyl and is required for survival at 37 degrees $\mathrm{C}$ and in vivo. Microbiology. 150, 1547-1558. doi: 10.1099/mic.0.26928-0

Kondori, N., Gilljam, M., Lindblad, A., Jonsson, B., Moore, E. R., and Wenneras, C. (2011). High rate of Exophiala dermatitidis recovery in the airways of patients with cystic fibrosis is associated with pancreatic insufficiency. J. Clin. Microbiol. 49, 1004-1009. doi: 10.1128/JCM.01899-10

Lanternier, F., Barbati, E., Meinzer, U., Liu, L., Pedergnana, V., Migaud, M., et al. (2015). Inherited CARD9 deficiency in 2 unrelated patients with invasive Exophiala infection. J. Infect. Dis. 211, 1241-1250. doi: 10.1093/infdis/jiu412

Lee, H., Chang, Y. C., Varma, A., and Kwon-Chung, K. J. (2009). Regulatory diversity of TUP1 in Cryptococcus neoformans. Eukaryot. Cell 8, 1901-1908. doi: 10.1128/EC.00256-09

Li, D. M., Li, R. Y., de Hoog, G. S., Sudhadham, M., and Wang, D. L. (2011). Fatal Exophiala infections in China, with a report of seven cases. Mycoses 54, e136-e142. doi: 10.1111/j.1439-0507.2010.01859.x

Lin, Y. P., Li, W., Yang, Y. P., Huang, W. M., and Fan, Y. M. (2012). Cutaneous phaeohyphomycosis caused by Exophiala spinifera in a patient with systemic lupus erythematosus. Lupus 21, 548-551. doi: 10.1177/096120331 1428460

Liu, O. W., Chun, C. D., Chow, E. D., Chen, C., and Madhani, H. D. (2008). Systematic genetic analysis of virulence in the human fungal pathogen Cryptococcus neoformans. Cell 135, 174-188. doi: 10.1016/j.cell.2008.07.046

Liu, O. W., Kelly, M. J. S., Chow, E. D., and Madhani, H. D. (2007). Parallel beta-helix proteins required for accurate capsule polysaccharide synthesis and virulence in the yeast Cryptococcus neoformans. Eukaryot. Cell 6, 630-640. doi: 10.1128/EC.00398-06

Matos, T., de Hoog, G. S., de Boer, A. G., de Crom, I., and Haase, G. (2002). High prevalence of the neurotrope Exophiala dermatitidis and related oligotrophic black yeasts in sauna facilities. Mycoses 45, 373-377.

Matos, T., Haase, G., and de Hoog, G. S. (2003). Molecular diversity of oligotrophic and neurotropic members of the black yeast genus Exophiala, with accent on E. dermatitidis. Antonie van Leeuwenhoek 83, 293-303.

Matsumoto, T., Matsuda, T., McGinnis, M. R., and Ajello, L. (1993). Clinical and mycological spectra of Wangiella dermatitidis infections. Mycoses 36, 145-155.

Mirza, S. H., Hannan, A., Ahmad, A., and Ahmad, M. (1993). Subcutaneous phaeohyphomycosis. J. Infect. 27, 75-78. 
Moreno, L. F., Feng, P., Weiss, V. A., Vicente, V. A., Stielow, J. B., and de Hoog, S. (2017). Phylogenomic analyses reveal the diversity of laccase-coding genes in Fonsecaea genomes. PloS ONE 12:e0171291. doi: 10.1371/journal.pone.0171291

Moyrand, F., and Janbon, G. (2004). UGD1, encoding the Cryptococcus neoformans UDP-glucose dehydrogenase, is essential for growth at 37 degrees C and for capsule biosynthesis. Eukaryot. Cell 3, 1601-1608. doi: 10.1128/EC.3.6.1601-1608.2004

Moyrand, F., Chang, Y. C., Himmelreich, U., Kwon-Chung, K. J., and Janbon, G. (2004). Cas3p belongs to a seven-member family of capsule structure designer proteins. Eukaryot. Cell 3, 1513-1524. doi: 10.1128/EC.3.6.1513-1524.2004

Moyrand, F., Fontaine, T., and Janbon, G. (2007). Systematic capsule gene disruption reveals the central role of galactose metabolism on Cryptococcus neoformans virulence. Mol. Microbiol. 3, 771-781. doi: 10.1111/j.1365-2958.2007.05695.x

Moyrand, F., Klaproth, B., Himmelreich, U., Dromer, F., and Janbon, G. (2002). Isolation and characterization of capsule structure mutant strains of Cryptococcus neoformans. Mol. Microbiol. 45, 837-849. doi: 10.1046/j.1365-2958.2002.03059.x

Muotoe-Okafor, F. A., and Gugnani, H. C. (1993). Isolation of Lecythophora utabilis and Wangiella dermatitidis from the fruit eating bat, Eidolon helvum. Mycopathologia 122, 95-100.

Nascimento, M. M., Vicente, V. A., Bittencourt, J. V., Gelinski, J. M., PrenafetaBoldú, F. X., Romero-Güiza, M., et al. (2017). Diversity of opportunistic black fungi on babassu coconut shells, a rich source of esters and hydrocarbons. Fungal Biol. 121, 488-500. doi: 10.1016/j.funbio.2017.01.006

Negroni, R., Helou, S. H., Petri, N., Robles, A. M., Arechavala, A., and Bianchi, M. H. (2004). Case study: posaconazole treatment of disseminated phaeohyphomycosis due to Exophiala spinifera. Clin. Infect. Dis. 38, e15-e20. doi: $10.1086 / 380840$

Nishimura, K., and Miyaji, M. (1983). Defense mechanisms of mice against Exophiala dermatitidis infection. Mycopathologia 81, 9-21.

ÒMeara, T. R., Hay, C., Price, M. S., Giles, S., and Alspaugh, J. A. (2010a). Cryptococcus neoformans histone acetyltransferase Gcn5 regulates fungal adaptation to the host. Eukaryot. Cell 9, 1193-1202. doi: 10.1128/EC.00098-10

ÒMeara, T., Norton, D., Price, M., Hay, C., Clements, M., Nichols, C., et al. (2010b). Interaction of Cryptococcus neoformans Rim101 and protein kinase A regulates capsule. PLoS Pathog 6:e1000776. doi: 10.1371/journal.ppat.1000776

Padhye, A. A., Ajello, L., Chandler, F. W., Banos, J. E., Hernandez-Perez, E., Llerena, J., et al. (1983). Phaeohyphomycosis in El Salvador caused by Exophiala spinifera. Am. J. Trop. Med. Hyg. 32, 799-803.

Padhye, A. A., Hampton, A. A., Hampton, M. T., Hutton, N. W., Prevost-Smith, E., and Davis, M. S. (1996). Chromoblastomycosis caused by Exophiala spinifera. Clin. Infect. Dis. 22, 331-335.

Padhye, A. A., Kaplan, W., Neuman, M. A., Case, P., and Radcliffe, G. N. (1984). Subcutaneous phaeohyphomycosis caused by Exophiala spinifera. Sabouraudia 22, 493-500.

Pascon, R. C., Ganous, T. M., Kingsbury, J. M., Cox, G. M., and McCusker, J. H. (2004). Cryptococcus neoformans methionine synthase: expression analysis and requirement for virulence. Microbiology 150, 3013-3023. doi: 10.1099/mic.0.27235-0

Patel, A. K., Patel, K. K., Darji, P., Singh, R., Shivaprakash, M. R., and Chakrabarti, A. (2013). Exophiala dermatitidis endocarditis on native aortic valve in a postrenal transplant patient and review of literature on E. Dermatitidis infections. Mycoses 56, 365-372. doi: 10.1111/myc.12009

Radhakrishnan, D., Jayalakshmi, G., Madhumathy, A., Banu, S. T., Geethalakshmi, S., and Sumathi, G. (2010). Subcutaneous phaeohyphomycosis due to Exophiala spinifera in an immunocompromised host. Indian J. Med. Microbiol. 28, 396-399. doi: 10.4103/0255-0857.71838

Rajam, R. V., Kandhari, K. C., and Thirumalachar, M. J. (1958). Chromoblastomycosis caused by a rare yeast like dematiaceous fungus. Mycopathol. Mycol. Appl. 9, 5-19.

Rajendran, C., Khaitan, B. K., Mittal, R., Ramam, M., Bhardwaj, M., and Datta, K. K. (2003). Phaeohyphomycosis caused by Exophiala spinifera in India. Med. Mycol. 41, 437-441.

Rath, P. M., Muller, K. D., Dermoumi, H., and Ansorg, R. (1997). A comparison of methods of phenotypic and genotypic fingerprinting of Exophiala dermatitidis isolated from sputum samples of patients with cystic fibrosis. J. Med. Microbiol. $46,757-762$.
Reese, A. J., Yoneda, A., Breger, J. A., Beauvais, A., Liu, H., Griffith, C. L., et al. (2007). Loss of cell wall alpha(1-3) glucan affects Cryptococcus neoformans from ultrastructure to virulence. Mol. Microbiol. 63, 1385-1398. doi: 10.1111/j.1365-2958.2006.05551.x

Reiss, N. R., and Mok, W. Y. (1979). Wangiella dermatitidis isolated from bats in Manaus, Brazil. Sabouradia 17, 213-218.

Revankar, S. G., and Sutton, D. A. (2010). Melanized fungi in human disease. Clin. Microbiol. Rev. 23, 884-928. doi: 10.1128/CMR.00019-10

Revankar, S. G., Patterson, J. E., Sutton, D. A., Pullen, R., and Rinaldi, M. G. (2002). Disseminated phaeohyphomycosis: review of an emerging mycosis. Clin. Infec. Dis. 34, 467-476. doi: 10.1086/338636

Rozas, J., and Rozas, R. (1995). DnaSP, DNA sequence polymorphism: an interactive program for estimating population genetics parameters from DNA sequence data. CABIOS 11, 621-625.

Shen, G., Wang, Y.-L., Whittington, A., Li, L., and Wang, P. (2008). The RGS protein Crg2 regulates pheromone and cyclic AMP signaling in Cryptococcus neoformans. Eukaryot. Cell 7, 1540-1548. doi: 10.1128/EC.00154-08

Shen, G., Whittington, A., and Wang, P. (2011). Wspl, a GBD/CRIB domain-containing WASP homolog, is required for growth, morphogenesis, and virulence of Cryptococcus neoformans. Eukaryotic. Cell 10, 521-529. doi: 10.1128/EC.00274-10

Shen, G., Whittington, A., Song, K., and Wang, P. (2010). Pleiotropic function of intersectin homologue Cin1 in Cryptococcus neoformans. Mol. Microbiol. 76, 662-676. doi: 10.1111/j.1365-2958.2010.07121.x

Silva, W. C., Goncalves, S. S., Santos, D. W., Padovan, A. C., Bizerra, F. C., and Melo, A. S. (2017). Species diversity, antifungal susceptibility and phenotypic and genotypic characterisation of Exophiala spp. infecting patients in different medical centres in Brazil. Mycoses 60, 328-337. doi: 10.1111/myc.12597

Singal, A., Pandhi, D., Bhattacharya, S. N., Das, S., Aggarwal, S., and Mishra, K. (2008). Pheohyphomycosis caused by Exophiala spinifera: a rare occurrence. Int. J. Dermatol. 47, 44-47. doi: 10.1111/j.1365-4632.2007.03430.x

Slifkin, M. (2000). Tween 80 opacity test responses of various Candida species. J. Clin. Microbiol. 38, 4626-4628.

Srinivas, S. M., Gowda, V. K., Mahantesh, S., Mannapur, R., and Shivappa, S. K. (2016). Chromoblastomycosis associated with bone and central nervous involvement system in an immunocompetent child caused by Exophiala Spinifera. Indian J. Dermatol. 61, 324-328. doi: 10.4103/0019-5154. 182425

Sudhadham, M., de Hoog, G. S., Menken, S. B., Gerrits van den Ende, A. H., and Sihanonth, P. (2010). Rapid screening for genotypes as possible markers of virulence in the neurotropic black yeast Exophiala dermatitidis using PCRRFLP. J. Microbiol. Meth. 80, 138-142. doi: 10.1016/j.mimet.2009.11.007

Sudhadham, M., Prakitsin, S., Sivichai, S., Chaiyarat, R., Dorrestein, G. M., Menken, S. B., et al. (2008). The neurotropic black yeast Exophiala dermatitidis has a possible origin in the tropical rain forest. Stud. Mycol. 61, 145-155. doi: 10.3114/sim.2008.61.15

Summerbell, R. C., Rosenthal, S. A., and Kane, J. (1988). Rapid method for differentiation of Trichophyton rubrum, Trichophyton mentagrophytes, and related dermatophyte species. J. Clin. Microbiol. 26, 2279-2282.

Teixeira, M. M., Moreno, L. F., Stielow, B. J., Muszewska, A., Hainaut, M., Gonzaga, L., et al. (2017). Exploring the genomic diversity of black yeasts and relatives (Chaetothyriales, Ascomycota). Stud. Mycol. 86, 1-28. doi: 10.1016/j.simyco.2017.01.001

Tesei, D., Marzban, G., Marchetti-Deschmann, M., Tafer, H., Arcalis, E., and Sterflinger, K. (2015). Protein functional analysis data in support of comparative proteomics of the pathogenic black yeast Exophiala dermatitidis under different temperature conditions. Data Brief 5, 372-375. doi: 10.1016/j.dib.2015.08.008

Tomson, N., Abdullah, A., and Maheshwari, M. B. (2006). Chromomycosis caused by Exophiala spinifera. Clin. Exper. Dermato. 31, 239-241. doi: 10.1111/j.1365-2230.2005.02006.x

Vicente, V. A., Attili-Angelis, D., Pie, M. R., Queiroz-Telles, F., Cruz, L. M., Najafzadeh, M. J., et al. (2008). Environmental isolation of black yeast-like fungi involved in human infection. Stud. Mycol. 61, 137-144. doi: 10.3114/sim.2008.61.14

Wang, L., Wang, C., Shen, Y., Lv, G., She, X., Zeng, R., et al. (2015). Phaeohyphomycosis caused by Exophiala spinifera: an increasing disease in young females in mainland China? Two case reports and review of five 
cases reported from mainland China. Mycoses 58, 193-196. doi: 10.1111/myc. 12295

Wang, P., Cox, G. M., and Heitman, J. (2004). A Sch9 protein kinase homologue controlling virulence independently of the cAMP pathway in Cryptococcus neoformans. Curr. Genet. 46, 247-255. doi: 10.1007/s00294-0040529-1

Wang, P., Nichols, C. B., Lengeler, K. B., Cardenas, M. E., Cox, G. M., et al. (2002). Mating-type-specific and nonspecific PAK kinases play shared and divergent roles in Cryptococcus neoformans. Eukaryot. Cell 1, 257-272. doi: 10.1128/EC.1.2.257-272.2002

Wills, E. A., Roberts, I. S., Del Poeta, M., Rivera, J., Casadevall, A., Cox, G. M., et al. (2001). Identification and characterization of the Cryptococcus neoformans phosphomannose isomerase-encoding gene, MAN1, and its impact on pathogenicity. Mol. Microbiol. 40:610-620. doi: 10.1046/j.1365-2958.2001.02401.x

Xue, C., Bahn, Y.-S., Cox, G. M., and Heitman, J. (2006). G proteincoupled receptor Gpr4 senses amino acids and activates the cAMPPKA pathway in Cryptococcus neoformans. Mol. Biol. Cell 17, 667-679. doi: 10.1091/mbc.E05-07-0699

Yurlova, N. A., and de Hoog, G. S. (2002). Exopolysaccharides and capsules in human pathogenic Exophiala species. Mycoses 45, 443-448. doi: 10.1046/j.1439-0507.2002.00807.x

Zalar, P., Novak, M., de Hoog, G. S., and Gunde-Cimerman, N. (2011). Dishwashers-a man-made ecological niche accommodating human opportunistic fungal pathogens. Fungal Biol. 115, 997-1007. doi: $10.1016 /$ j.funbio.2011.04.007

Zeng, J. S., and De Hoog, G. S. (2008). Exophiala spinifera and its allies: diagnostics from morphology to DNA barcoding. Med. Mycol. 46, 193-208. doi: $10.1080 / 13693780701799217$
Zeng, J. S., Sutton, D. A., Fothergill, A. W., Rinaldi, M. G., Harrak, M. J., and de Hoog, G. S. (2007). Spectrum of clinically relevant Exophiala species in the United States. J. Clin. Microbiol. 45, 3713-3720. doi: 10.1128/JCM.02012-06

Zhang, S., Hacham, M., Panepinto, J., Hu, G., Shin, S., Zhu, X., et al. (2006). The Hsp70 member, Ssa1, acts as a DNA-binding transcriptional coactivator of laccase in Cryptococcus neoformans. Mol. Microbiol. 62, 1090-1101. doi: 10.1111/j.1365-2958.2006.05422.x

Zhu, X., and Williamson, P. R. (2003). A CLC-type chloride channel gene is required for laccase activity and virulence in Cryptococcus neoformans. Mol. Microbiol. 50, 1271-1281. doi: 10.1046/j.1365-2958.2003. 03752.x

Zupancic, J., Novak Babic, M., Zalar, P., and Gunde-Cimerman, N. (2016). The Black Yeast Exophiala dermatitidis and other selected opportunistic human fungal pathogens spread from dishwashers to kitchens. PLOS ONE 11:e0148166. doi: 10.1371/journal.pone.0148166

Conflict of Interest Statement: The authors declare that the research was conducted in the absence of any commercial or financial relationships that could be construed as a potential conflict of interest.

The reviewer JAMÁ and handling Editor declared their shared affiliation.

Copyright (C) 2017 Song, Laureijssen-van de Sande, Moreno, Gerrits van den Ende, Li and de Hoog. This is an open-access article distributed under the terms of the Creative Commons Attribution License (CC BY). The use, distribution or reproduction in other forums is permitted, provided the original author(s) or licensor are credited and that the original publication in this journal is cited, in accordance with accepted academic practice. No use, distribution or reproduction is permitted which does not comply with these terms. 